\title{
Integrating Visual Literacy Training into the Business Curriculum. A Case Study at Dublin Business School
}

\author{
Susan Sweeney \\ School of Business and Law \\ Dublin Business School \\ Dublin, Ireland. \\ David Hughes \\ Library \\ Dublin Business School \\ Dublin, Ireland.
}

(C) Susan Sweeney and David Hughes. This work is licensed under the Creative Commons Attribution-NonCommercial-ShareAlike 4.0 International License. To view a copy of this license, visit https://creativecommons.org/licenses/by-nc-sa/4.0/ .

\begin{abstract}
Visual literacy, the ability to interpret, analyse and create visual material, is an increasingly crucial skill for today's graduates. However, this importance has not yet led to its teaching being widely introduced into the third-level curriculum. This study uses a constructivist and social constructivist approach to introduce a visual literacy element to a business curriculum. This took the form of five projects: creation of an album cover, a poster and artefact presentation, a walk along a river to facilitate learning via visual stimulation, abstract art creation through use of image manipulation software and a photography exhibition.

Students responded positively to the projects; self-reported improvement in skills and confidence are in line with results of previous studies. Students also noted the ease of use of PowerPoint as an image manipulation tool.

Keywords: Visual literacy; Visualisation; Business education
\end{abstract}

\section{Introduction}

Today's business environment is very visually oriented. Globalisation mandates an increased visual element to business communications. Organisations can spend large sums of money on logo design, while advertising - an image-rich discipline has become almost ubiquitous. The need for graduates to be visually literate in this technological age was never greater. Baker (2006) suggests that business communication modules, for example, are "ideal for teaching visual communications principles and techniques."

Debes (1968) identifies visual literacy as the "ability to interpret, negotiate and make meaning from information presented in the form of an image" and is based on the idea that meaning can be communicated through the "reading" of images. Television, the internet, new information and communication technologies (e.g. smartphones, 
laptops and tablets) as well as film and advertising industries, all contribute to the "flood of visual messages" in which modern society is awash. Bamford (2003) states that there are many forms of visual communication, including gestures, objects, signs and symbols, and shows the ubiquity of visual material; for example: dance, film, fashion, hairstyles, exhibitions, public monuments, interior design, lighting, computer games, advertising, photography, architecture, and art. Using new information and communication technologies it is now easier to create and manipulate images than it has ever been in the past, hence, more recent definitions of visual literacy have been expanded to include the ability to not just analyse or interpret, but also to create visual material (Hattwig et al., 2013).

Visual literacy is increasingly essential for communicating and navigating the modern world. The literature review of this study indicates that this implementation of visual literacy modules across the higher education curriculum has not been widespread. Blummer (2015) provides a literature review of visual literacy training in academic institutions. Many of the studies that she cites are pilot projects or are implemented at course or departmental level as opposed to institutionally. Hill (2003) cited in Blummer (2015, p. 128) argues that higher education lacks a 'pedagogy of visual rhetoric'. Daly (2003) also cited in Blummer (2015, p. 37) argues that 'visual media are perceived as inferior communication forms when compared to print'. This lack of visual rhetoric contradicts the requirements of the modern curriculum and of industry.

\section{Research question}

Visual literacy instruction is delivered in a small number of business programmes at Dublin Business School using a social constructivist approach. This paper seeks to address the following research questions:

1. Does visual literacy impact students' confidence levels?

2. Does visual literacy impact students' technical skills?

3. Do students feel that visual literacy training enhances their employability?

4. How do students rate the learning experience in a visual literacy initiative?

The above research questions are explored in the context of an extensive overview of the literature and a detailed outline of the visual exercises that are used at DBS and of the social constructivist teaching approach that underpins them.

\section{Literature review}

\section{Early definitions}

A Google Scholar search for the phrase "visual literacy" returns around 33,000 results. However, more than $33 \%$ of these results were published in the last 5 years, suggesting that it is a topic of growing scholarly interest. This coincides with a growing use of multimedia in all areas of everyday life. The field of education is no exception: although illustrated textbooks date from the 17th century, today the impact of visual material on the learning process is growing ever deeper. 
Although visual literacy was first defined by John Debes in 1968, the concept is far older; the poet Simonides of Ceos asserted "Words are the images of things" (Benson, 1997). Similarly, Aristotle stated "without image, thinking is impossible" (Benson, 1997). Going back farther than Ancient Greece, Egyptian hieroglyphs picture with meaning - form a bridge between images and words.

Debes' definition of visual literacy is not the only one extant. Wileman (1993) defined visual literacy as "the ability to 'read,' interpret, and understand information presented in pictorial or graphic images". Associated with this is visual thinking "the ability to turn information of all types into pictures, graphics, or forms that help communicate the information". Heinich et al. (1999) have a similar definition: "the learned ability to interpret visual messages accurately and to create such messages". Stokes (2001), in a comprehensive review of the literature, defined visual literacy as "the ability to interpret images as well as to generate images for communicating ideas and concepts".

\section{Visual literacy in the technological age}

More recently, definitions of visual literacy have shifted in meaning to reflect modern day trends (such as increased technology use). Technology also facilitates more readily the creation and dissemination of visual images. Stokes (2001) suggests that the printing press led to a separation of words (type) and pictures (illustrations), which is now being reversed because of the ability of computers to graphically display information, "allowing for deeper insights as well as heightened abilities to communicate data and concepts". Therefore incorporated into more recent definitions are "communication", "messages" and "creating" or "composing" (Hattwig et al., 2013). For example, Johnson (2006) states that "visually literate individuals have an imaginative ability to see and understand the messages communicated with images, as well as to create, modify, and use visual cues and images", while Metros (2008) talks of the "ability to decode and interpret (make meaning from) visual messages and also to be able to encode and compose meaningful visual communication". The best definitions of visual literacy according to Brumberger (2011) include both "an interpretative and a productive component". Thus contemporary definitions require the ability to not only analyse and interpret visual material, they require the ability to create visual material too (Hattwig et al., 2013).

\section{Benefits of visual literacy}

Yenawine (1997) states that visual literacy promotes critical and creative thinking. Flynt and Brozo (2010) list a variety of benefits to teaching children visual literacy. These include better verbal skills; self-expression and ordering of ideas; motivation and interest in a variety of subjects; better chances of reaching the disengaged; improved self-image and relationship to the world and more self-reliance, independence, and confidence. Silverman and Piedmont (2016) state that their students have more self-belief and are better able to express themselves, a conclusion shared by Dinham et al., (2007) who assert that visual literate students "are active participants in the process of communicating ideas and making new meanings". Bintz (2016) suggests that visual literacy promotes leadership skills such as critical thinking, problem-solving, visual communication and self-reflection. AliKhan (2011) notes the potential to better engage and motivate students in the context of visual literacy education, and suggests that "it is becoming increasingly 
important that we as educators harness the vibrant power of visual communication, and that we try to find ways to engage our students in working together with us in decoding images and in producing them".

\section{The educational response}

The benefits of visual literacy have not gone unnoticed by educators and policy makers, who have developed an interest in the role that visual representation can play in education. There is a perceived need for a change in curricula to help navigate a more visually-oriented world. Many researchers believe that although students live in a visually saturated society, this exposure does not necessarily lead to better visual literacy (e.g. Felten, 2008; Avgerinou, 2009; Flynt and Brozo 2010; White, Breslow and Hastings, 2015). Bleed (2005) noted that "although visuals and media have become ubiquitous in our society during the 21 st century, words and text still dominate literacy efforts within education" while Ali-Khan (2011) declared that "Schools value one language system and students others - this prompts me to question the degree to which schools are equipping students to decode and read a world that is thick with visual knowledge". In a similar vein, Silverman and Piedmont (2016) note "Years are spent teaching students grammar and paragraph construction so that they can become strong written communicators, but rarely is the same attention spent on the elements of visual communication". The result, Emanuel and Challons-Lipton (2013) suggest, is "that today's college students may be adrift in a sea of images with little ability to see beyond their own generation", while Pauwels (2008) asserts that those who are not visually literate are only partially literate.

\section{Curricula integration}

With regard to studies on the teaching of visual literacy, there is as much literature on first and second-level as third level teaching. It is logical to teach visual literacy at an early age as Berger (1973) explains, "Seeing comes before words. The child looks and recognizes before it can speak". Lopatovska et al. (2016) describe teaching visual literacy to young children using art images. Mbelani (2008) selfreflects upon teaching and assessing visual literacy in a South African secondary school. Zambo used visual literacy to help adolescents understand how images influence their lives. Stafford (2011) outlines the use of picture books, film,

At third level the teaching of visual literacy has been introduced across the curriculum. For example in: art and design (Andrews, 2016) statistics (Young and Ruediger, 2016), dermatology (Griffin et al., 2016), library and information science (Beaudoin, 2016), inter-disciplinary studies (Little, Felten and Berry, 2015), geography (Hollman, 2014), science, technology, engineering and mathematics (Cook, Teaff and Cook, 2015), politics and international relations (Holland, 2014), teacher training (Wilhelm, 2005) and art and computer science (Eber and Wolfe, 2000).

The aforementioned studies illustrate breadth of visual literacy training rather than depth within educational curricula. They also indicate that the integration of visual literacy training within the curricula, whilst commendable, remains in its infancy and tends to be ad hoc and informal (non-accredited) by nature. 


\section{Pedagogical approach}

Visual literacy is taught not only as an end in itself but also as a method of improving students' learning skills - with mixed results. Chanlin (1998) found that while the use of graphics enhanced the learning experience, the effect was dependent upon the prior knowledge of the students. Ernst, McGahan and Harrison (2015) set students the task of producing an animated video in an attempt to inculcate creative visual literacy. There was no change in depth of topic understanding between this cohort and previous years', but students who produced the video showed poorer learning outcomes. Ernst, McGahan and Harrison conclude that producing the video was disruptive to wider learning because of the involved and novel nature of the task. Other initiatives have been more successful: Naghshineh et al. (2008) observed that formal art observation training improved medical students' visual diagnostic skills, while Milkova et al. (2013) used analysis of artworks to develop higher-level thinking skills and prompt greater engagement with course material in undergraduate biology students.

The literature demonstrates engagement with visual literacy training across a broad range of subject disciplines and with varying degrees of success in terms of pedagogical approaches. More formalised integration of visual literacy training within the curricula would ensure standards in relation to pedagogical approaches with proven outcomes. Studies with negative outcomes remain useful, however, in relation to informing best practice as in what approaches don't work.

\section{Business curricula integration}

Business is a discipline that would benefit from increased visual literacy training. We live in a world in which images exert great influence in how we conduct business. In an era of globalisation, using visuals to communicate can overcome language barriers. The sub-disciplines of advertising and marketing are rich in imagery and the number of adverts seen by people in urban areas more than doubled in the period between 1976 and 2006 (Story, 2007).

Although scholars and researchers have been repeatedly calling for the inclusion of a visual literacy component in business courses (Bernhardt, 1986; Brumberger, 2005; Kostelnick, 1988; Rosenquist, 2012) few have picked up the gauntlet. Schultz (2006) included the use of visual enhancements in a creativity and communication module of a marketing course, stating that having students able to express themselves visually helps make them more effective communicators who have a competitive edge in the market place. Baker (2006) offers suggestions on the integration of visual literacy components into business communication courses, asserting that the addition of this visual material will give students greater ability to produce textually and visually powerful documents. Andrews (2016) discusses a visually literacy module, which, although primarily designed for art and design students, can easily be adapted for business courses. Toth (2013) describes an approach to teaching infographics in a business course, which involves both analysing and creating infographics. Siu-Kay (2010) describes an elective module in which business students are introduced to visual semantics and syntax and then design business promotional materials. Siu-Kay notes that the course is very 
popular and, despite the maximum class size increasing by $25 \%$, it is always fully subscribed.

Studies pertaining to integration of visual literacy into the business curriculum illustrate successful approaches using a wide range of media already embedded and ubiquitous in the business world such as PowerPoint and infographics. Additionally the aforementioned studies illustrate that visual literacy training can enhance soft as well as technical skills for the business world such as leadership and communication skills.

\section{Visual literacy education in Ireland}

There is a paucity of academic literature on the use of visual literacy in an Irish education setting. Existing studies focus on visual literacy at first and second level predominately. In an Irish context, visual literacy is often considered a component of a wider definition of literacy. Daly (2015) mentions visual literacy in passing while discussing a digital literacy framework to support teaching of special needs students, while Barnes et al. (2007) touch upon visual literacy in their report on critical media literacy in Ireland. Danos (2014) reviews the emergence of graphicacy "otherwise known as visual literacy" in a number of countries noting that Ireland has a "long tradition of graphical education, which has typically been associated with vocational education." Seery, Lynch and Dunbar (2011) review the nature and evolution of second level graphical education in Ireland.

Butler (2013) suggests that the integration of visual and digital literacy into the school curriculum can improve oral and written language development in a class of 6-8 year olds. Sweeney-Burt (2014) explored primary school children's visual literacy while implementing a technique for telling and presenting stories using digital media.

Holland, O'Sullivan and Arnett (2015) explore visual literacy within the higher education environment by exploring the effect on cognitive load of including images within histology exam multiple-choice questions.

\section{Educational standards}

Despite much discussion there does not appear to be any co-ordinated attempt to standardise requirements to teach visual literacy. Bamford's white paper (2003) suggested strategies to promote visual literacy in the classroom, advocating that the teacher should provide creative experiences centred on technology noting that it is not a requirement for teachers to be technical "whizzes". The New Media Consortium (2005) asserted "21st century literacy is multimodal" with a strong visual element and recommended that teachers be trained with these multimodal skills. Felten (2008) stated that "the proliferation of literacies, and the emergence of new technologies that blend text and image, suggest that the time is right to rethink the very concept of literacy." Felten also noted that the American Association of Colleges and Universities 2002 Greater Expectations report suggested that one of the core characteristics of an "empowered learner" would include the capacity to effectively communicate visually. This idea was missing from their follow-up report, released in 2005 , suggesting that the importance of visual literacy is not consistently stressed. 
Several educational initiatives merit a mention. At second level, the American Common Core State Standards Initiative includes several standards that support the teaching of visual literacy (Finley, 2014), while at third-level the Association of College Research Libraries (ACRL 2012) published their visual literacy competency standards for higher education.

Figure 1: Visual literacy array

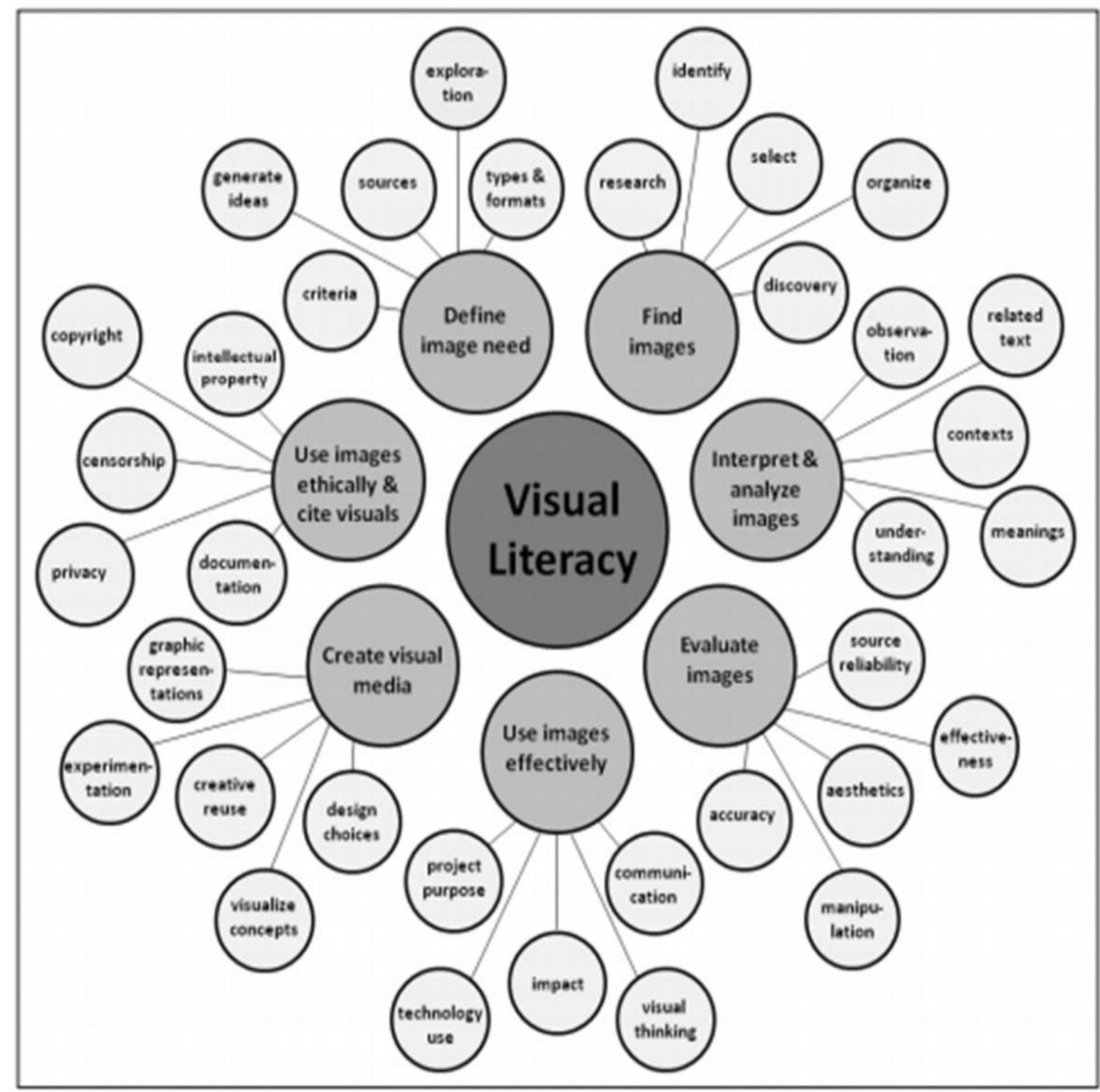

Source: based on ACRL's Visual Literacy Standards by D. Hattwig, K. Bussert, A. Medaille and J. Burgess. Copyright 2013 The Johns Hopkins University Press. This image originally appeared in PORTAL: LIBRARIES AND THE ACADEMY, Volume 13, Issue 1, January 2013, p. 75. 
In Europe, there is an ongoing project funded by the Lifelong Learning Programme of the European Union that brings together specialists in didactics, curriculum developers, teacher trainers and scientists working in arts, design, art education and visual communication (60 researchers in total), with the aim of developing a Common European Framework of Reference for Visual Literacy (ENViL, 2014). The ENViL framework creates a prototype of a "Common European Framework of Reference for Visual Literacy - CEFR_VL“. This framework describes competencies that European citizens must have in the field of fine arts and applied arts (architecture and design) as well as the everyday visual culture when they participate in society and culture as responsible citizens. The framework "aims to be a tool for the development of curricula, lesson plans and assignments as well as assessment instruments" (Wagner and Schönau, 2016 cited in ENViL, 2014).

\section{Training the teachers}

To facilitate the integration of visual literacy into the curriculum, it is essential that teachers acquire some experience and expertise in teaching visual literacy. Bleed (2005) mentions the need to integrate visual literacy training into teacher education courses. Fabian (2005) describes possible approaches to training teachers to effectively use visual resources including a train the trainer faculty immersion programme as well as individual and group training sessions scheduled at convenient times and of suitable duration. Fabian also recommends that there must be 'takeaway' documentation and skills from training sessions. She also recommends that faculty engaging in visual literacy instruction demonstrate real life application of skills using multiple resources/interfaces and active learning strategies. Alpan (2015) found that pre-service teachers benefit from visual literacy training.

Little, Felten and Berry (2015), in a special themed edition of New Directions for Teaching and Learning, highlight seven general suggestions and strategies for faculty (and others) working to develop visual literacy in classrooms and across the curriculum. The first of their seven general suggestions is "determining which learning goals or outcomes you want to teach with or through visual images...in deciding how and when to use them in your courses.' (p. 87). Subsequent steps include planning assignments or classroom activities that align with these goals or outcomes; consider the ways in which experts and novices see differently; scaffold assignments to help students to develop visual and disciplinary expertise; model professional integrity for image use and help students understand current ethical and legal practices; make visual literacy a long term part of your teaching practice and consider ways to share what you and your students learn with others.

\section{Summary}

In summary, there are a number of definitions of visual literacy, with a consensus forming around the requirement to both analyse and create visual material exploiting new technologies. Business students require a high level of visual competence to be adequately prepared for the highly visual nature of business communications in the 21 st century. Studies indicate the potential of visual literacy to enhance both soft and technical skills for the modern workplace. Studies also show the development of informal visual literacy education at first, second and third level across a range of subject disciplines. More widespread practice of visual literacy education is required 
at all levels to prepare students for a significantly more visual, as opposed to textual, world. Encouragingly, standards and resources are being developed by a number of agencies to help underpin this going forward.

Pedagogical approach to visual literacy instruction at Dublin Business School Visual literacy instruction at Dublin Business School is delivered using both a constructivist and social constructivist framework. The roots of social constructivism lie in the work of Vygotsky (1978) who stressed the fundamental role of social interaction in the development of cognition. He believed that meaning is created in the context of community and that social interactions from guided learning experiences facilitate the co-construction of knowledge. Vygotsky's theory of learning differs from his contemporary Piaget (2002), who believed that children's cognitive development is derived from independent explorations during which they construct knowledge of their own.

A social constructivist teaching approach is ideally suited to the delivery of visual literacy education. Visual literacy instruction at Dublin Business School is active and dynamic during which discussion and collaboration is encouraged. Students work together in groups to create artefacts. The social interaction of the group in the learning environment is therefore key. Equally important, however, is the focus on the individual's learning because of his or her interaction in the group. Papworth, (2016) states that "in social constructivist classes, collaborative learning is a process of peer interaction that is mediated and structured by the tutor".

The characteristic of a social constructivist teaching paradigm is that 'students learn most effectively by engaging in carefully selected problem solving activities, under the close supervision and coaching of an educator' (Hanson and Sinclair, 2008, p. 170). Teaching methods (Hanson and Sinclair, 2008) focus on realistic problems; students working collaboratively in small groups to solve the problem; groups exercise self-management and direction; teachers and tutors scaffold this process. Little (2015), as referred to in the literature review of this study, also refers to the necessity of scaffolding assignments.

Branton (1999), cited by Stokes (2001), links visual literacy instruction with constructivist learning. An extensive review of the literature found no studies explicitly referring to social constructivism as a pedagogical framework for visual literacy instruction. This is also reinforced by Blummer's 2015 extensive review of visual literacy initiatives in academic institutions in which there is explicit reference to social constructivism as an educational strategy.

A number of papers referred to in the literature review of this section describe pedagogical approaches to visual literacy instruction that have some of the characteristics of social constructivism, although the authors have not explicitly labelled them as such, indicating the potential for the adoption of this learning paradigm. For example Fabian (2005) discusses a 'learner centred approach' in which learners 'engage in real problem or case based examples'. Andrews (2016) uses group/collaborative work for visual literacy instruction. 
Visual literacy education is delivered at Dublin Business School within the business curriculum by one of the authors of the paper, Susan Sweeney. She has two Masters Qualifications: the first in IT in Education and the second in Multimedia. She also has an undergraduate degree in Communications Technology and teaches visual literacy via five separate projects which culminate in the staging of visual exhibitions. The production of a visual exhibition by students embodies a social constructivist approach in terms of student collaboration and the co-creation of knowledge mediated by Susan Sweeney as lecturer. A visit to the gallery of photography in Temple Bar Dublin preceded four out of the five projects. Students were introduced to concepts of creative design as well as the principles of curating a visual exhibition during their gallery visit. Students were also invited to visit art gallery spaces online.

Figure 2: Student visit to the Gallery of Photography

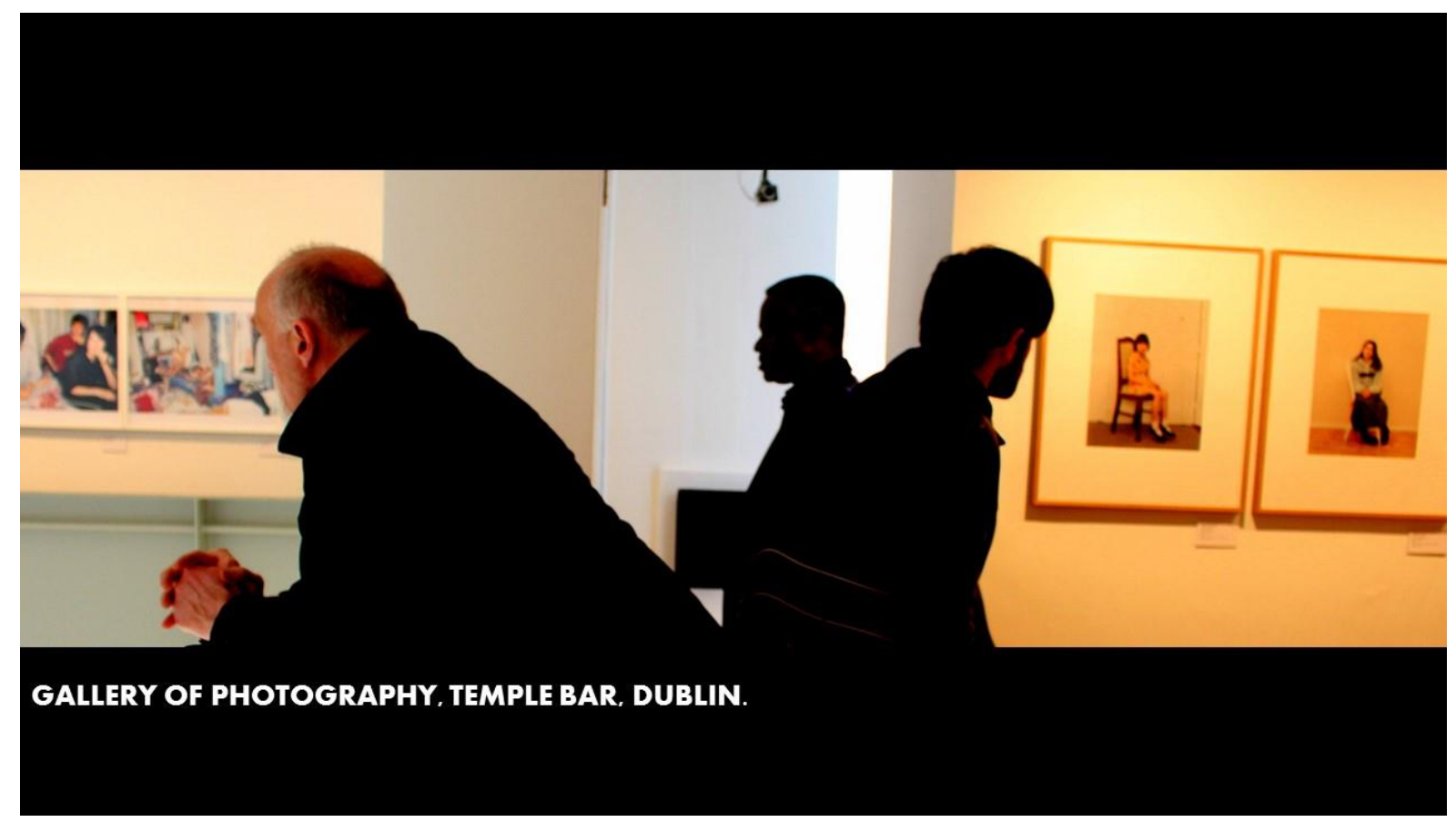

\section{Five visual literacy projects at Dublin Business School}

\section{Project 1: Collaborative album cover installation and exhibition}

The aim of the album cover project is to facilitate learning via visual engagement and digital manipulation using existing images owned by the student. The premise is that all students have access to a repository of images on their social media platforms. These images can be reconstructed and reimagined to generate a new and alternative narrative. With a collaborative constructivist approach, multiple images as a collective piece were reconstructed to form a single visual installation in an arts city centre exhibition space in Dubli 
Students 'drag and drop' chosen images from Facebook to a prepared template in PowerPoint. The student manipulates the image and incorporates an album cover name or logo to complete their digital image. The students produce the final image as a printed colour album cover. The lecturer plays a significant role in directing students to choose images with strong semiotic and aesthetic value. 70 individual artefacts were exhibited as one installation piece in Filmbase, a gallery space in Dublin. Learning outcomes from this project include the notion of reimaging and reconstructing an image from a personal digital repository, visual literacy, aesthetic and form and IT skills in the form of formatting, printing and curation using the cloud.

Learning outcomes and amplification of learning:

- Collaborative learning

- $\quad$ Active learning

- $\quad$ Problem solving skills

- $\quad$ Exhibition of work

- $\quad$ Aesthetic

- Digital curation

- $\quad$ Digital image manipulation

- $\quad$ Digital and technical proficiency: file extensions, file resizing, sharing documents on the cloud using Google Drive.

The above exercise and learning outcomes are typical of a social constructivist approach. These are also highly valued skills in the business world.

Figure 3: Album cover installation at Filmbase, Temple Bar, Dublin

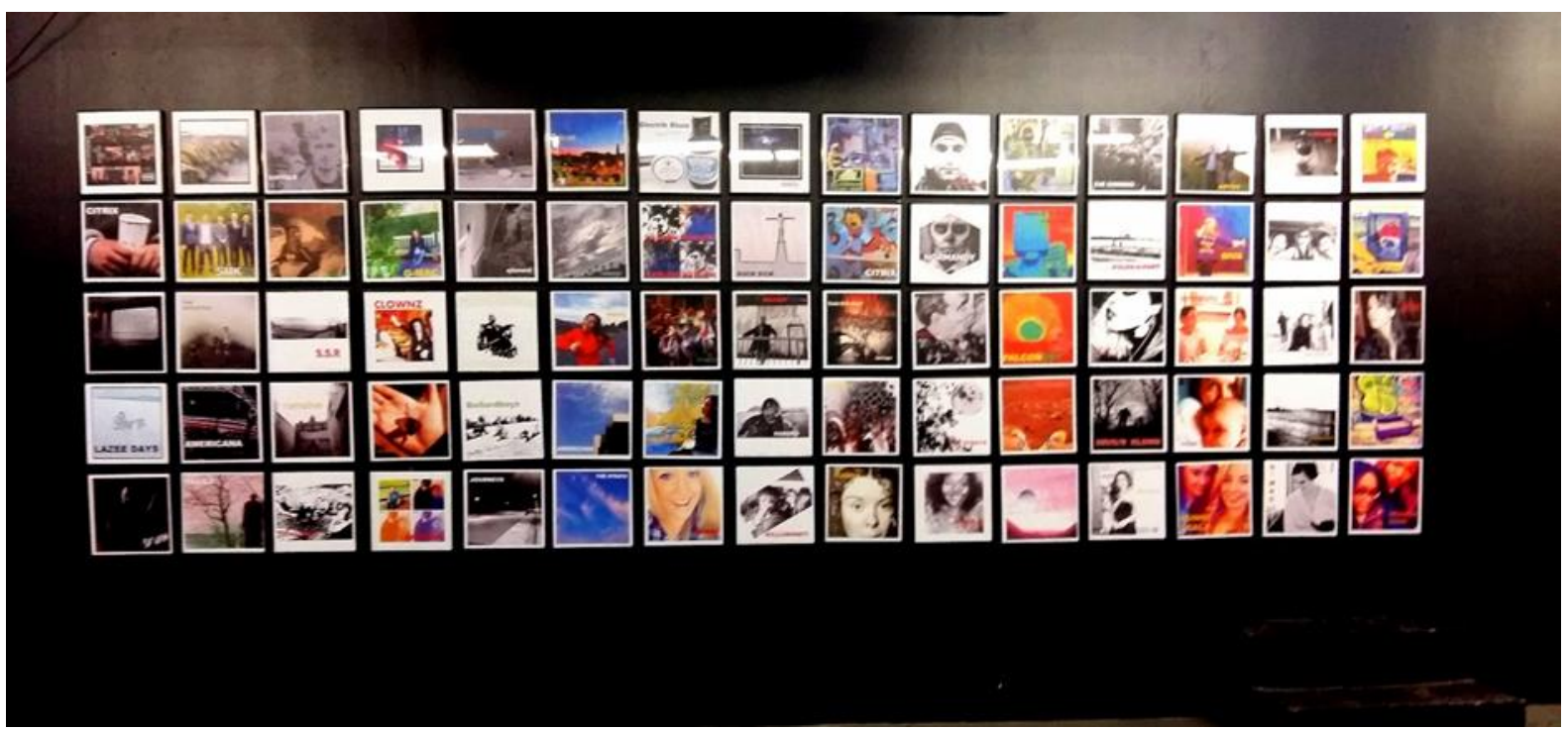




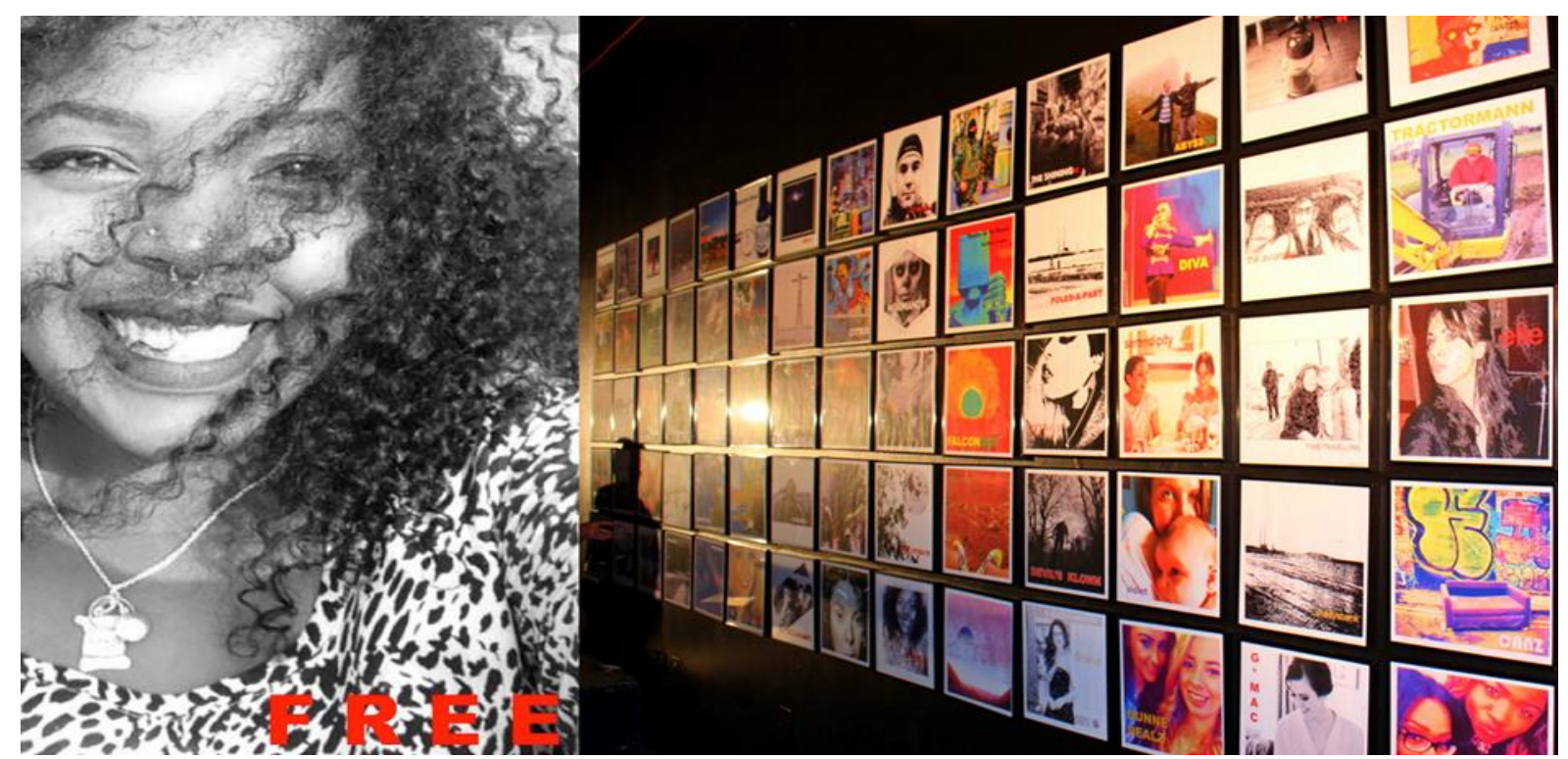

\section{Project 2: Poster and artefact presentation and exhibition}

Momentum students (Government activation business programme) were invited to create a scholarly poster about a subject of their choosing. These posters were exhibited in a public exhibition space at Dublin Business School. Students were encouraged to pick a subject or theme that they were passionate about. As part of the exhibition, students were also asked to bring along an artefact that represented the subject matter of their poster. Artefacts that students brought to the exhibition included souvenir coins, an archery bow; pitch and putt equipment, fencing foil and helmet, homemade pancakes, sign language methodology and fashion accessories. 
Figure 5: Poster exhibition with artefact. Diploma in Business Studies (Momentum Programme
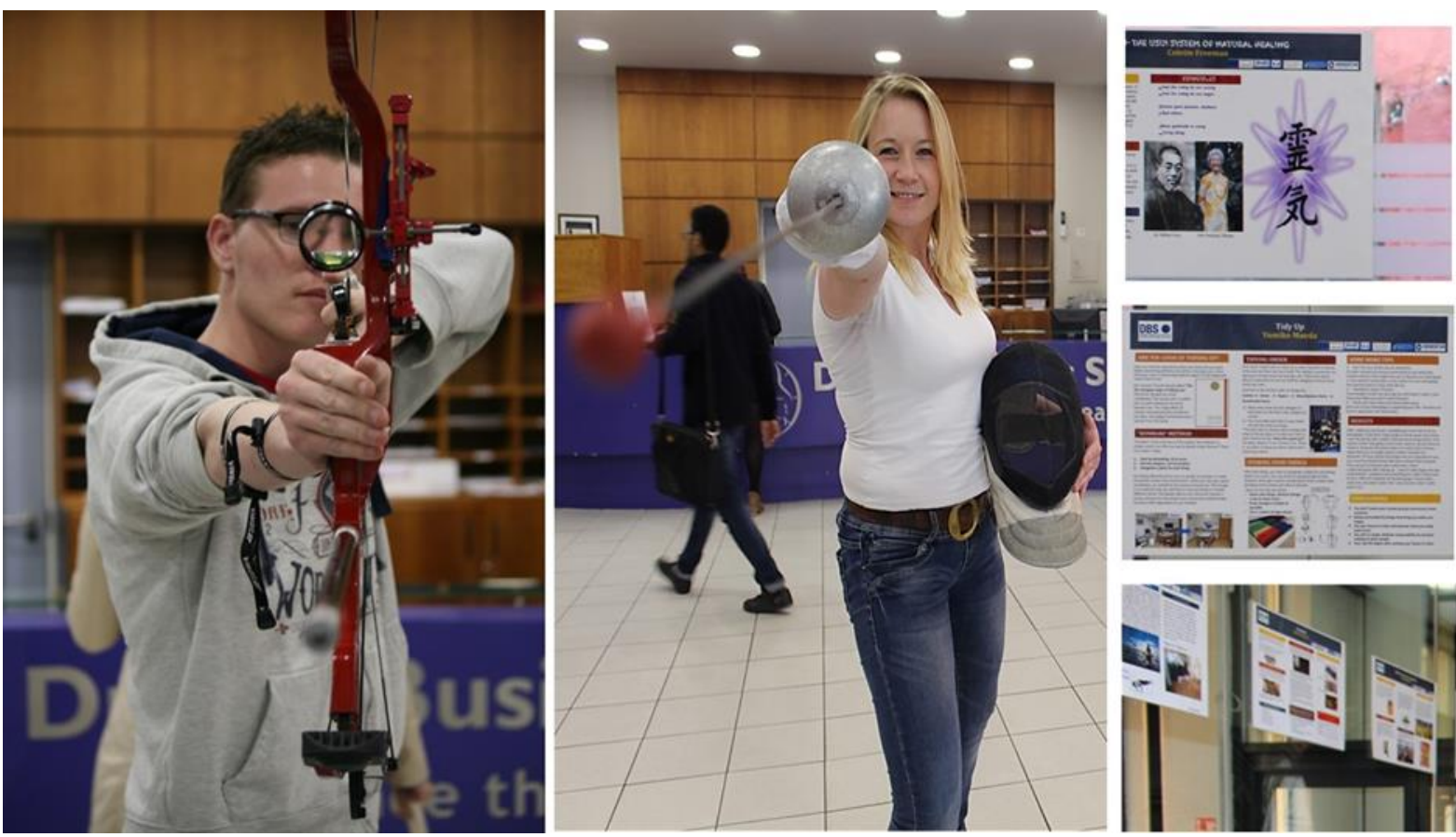

The aim of the poster project is to facilitate learning via a visual presentation that showcases Momentum students' scholarly research in an area of interest. The purpose of the poster is to present a piece of work for display which stimulates an exchange of ideas between the presenter and the audience reading the poster. The poster format has distinct visual attributes. The constraints of the scholarly poster template in PowerPoint forced students to display information in a particular format necessitating a great deal of experimentation with imagery and layout. This improvisation also led to enhanced digital and technical proficiency. The role of the teacher in this project was significant as some students on the Momentum programme were long-term unemployed and required extra support and encouragement. The lecturer teased out various ideas with students to assist with the determination of their subject choice for the poster.

During this project, the student must consider their audience, decide on a narrative/message, adhere to presentation requirements and describe a process or methodology. Students also experimented with different layout concepts and work through a series of drafts to guarantee the quality of the final product. The student engages with file formatting by converting their PowerPoint poster to a print ready PDF document. Eighty-four posters were exhibited in the main foyer of the Dublin Business School campus.

Learning outcomes:

- Collaborative learning.

- $\quad$ Active learning 
- $\quad$ Problem solving skills

- $\quad$ Exhibition of work

- $\quad$ Aesthetic

- $\quad$ Performance and presentation skills

- Digital curation

- $\quad$ Digital image manipulation

- $\quad$ Digital and technical proficiency: file extensions, file resizing, sharing documents on the cloud using Google Drive.

\section{Project 3: Riverwalk: collaborative photo, installation and exhibition}

The aim of the Riverwalk project is to facilitate learning via visual stimulation, active visual experimentation and image curation to form a photographic showcase. Students from the Higher Diploma in Business programme (level 8) visited the Gallery of Photography in Dublin. Here they viewed and wrote a reflective blog about a photo exhibition (Mother River) that concerns a river walk in China undertaken by photographer Yan Wang Preston. Yan photographed her river journey experience over thirty days. This Mother River exhibition was the inspiration behind the Riverwalk project.

The Higher Diploma in Business Students were requested to write a reflective blog piece about their visit to the Mother River exhibition. They were subsequently invited on a class excursion to the River Dodder in Dublin where they followed the path of the river over a three-hour visit. Prior to following the route, students were given general instruction concerning the rule of thirds in photography, the notion of texture in composing an image and they were encouraged to look for patterns in nature. During the walk students took photographs, sixty of which were exhibited as part of a shared installation with Arts students in an exhibition space at Filmbase, Temple Bar, Dublin.

Learning outcomes:

- $\quad$ Collaborative learning.

- $\quad$ Active learning

- $\quad$ Problem solving skills

- $\quad$ Exhibition of work

- Aesthetic

- Digital curation

- Digital image manipulation

- $\quad$ Digital and technical proficiency: file extensions, file resizing, sharing documents on the cloud using Google Drive. 
Figure 6: Riverwalk with 2D sphere exhibition

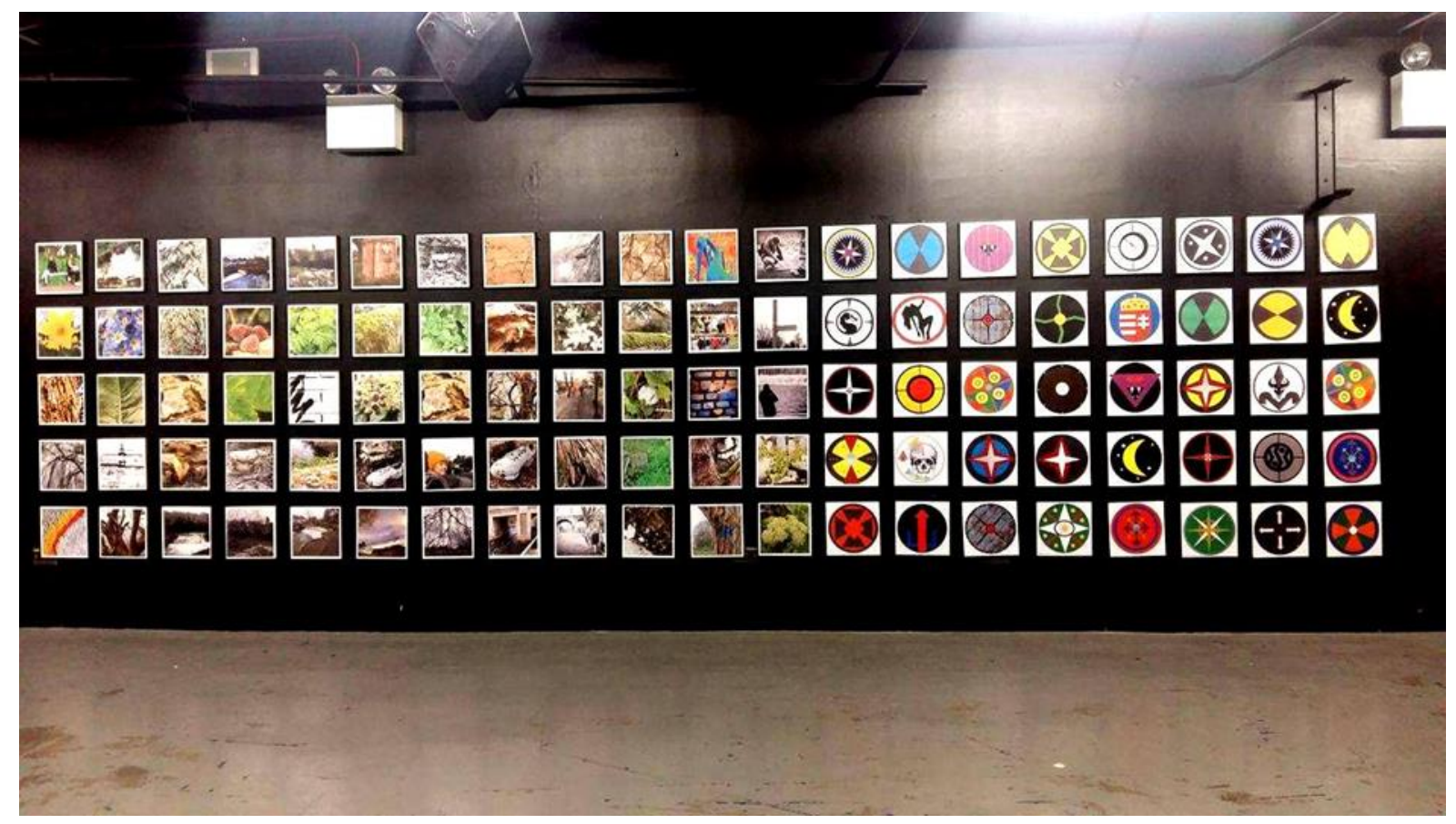

Figure 7: River images by Higher Diploma in Business students (Level 8)

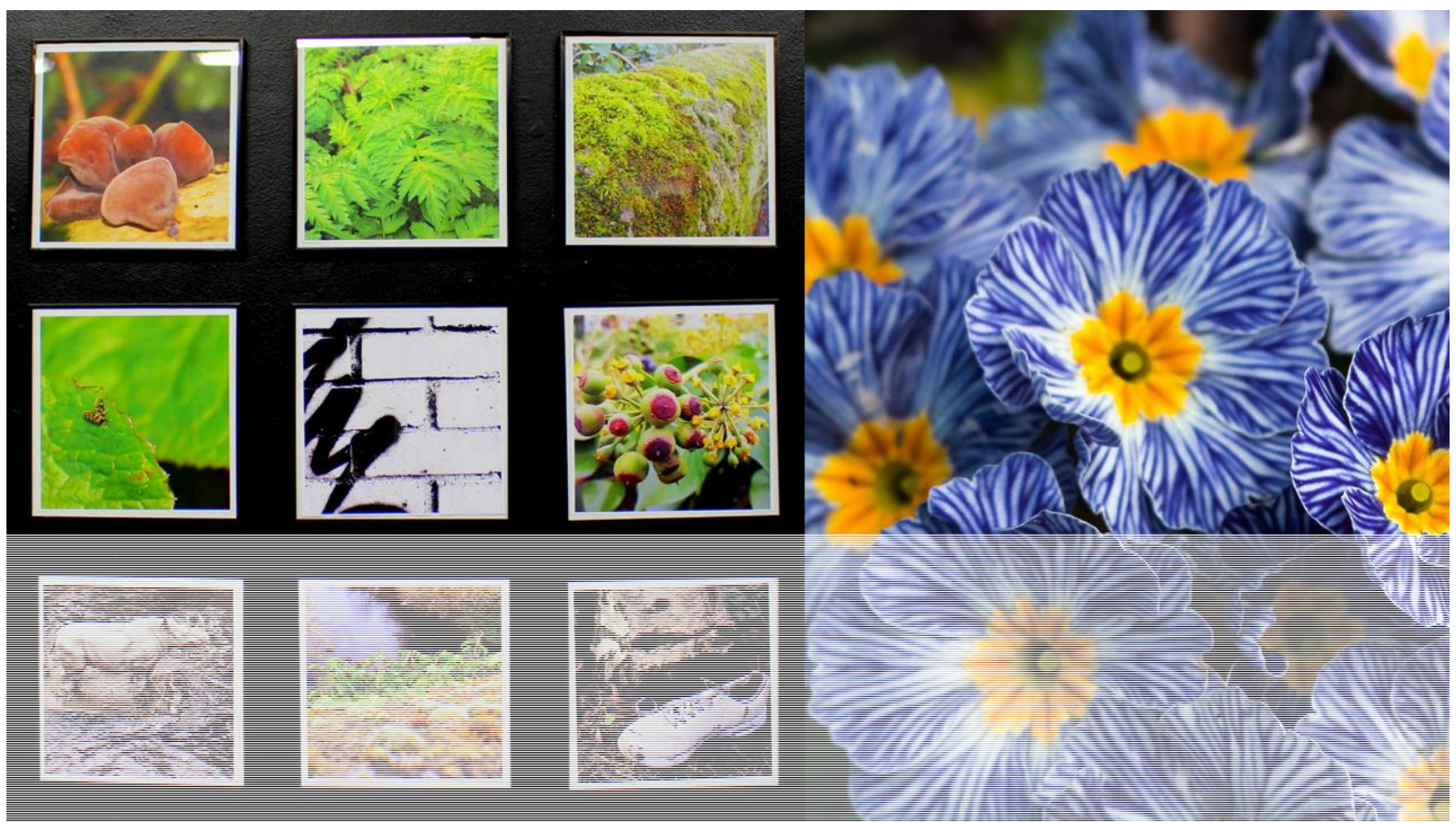

Project 4: Abstract art image

This is a collaborative image project involving installation and exhibition of digital content for a marketing event. The aim of the abstract image project is to facilitate 
the acquisition of design skills for digital marketing students at Dublin Business School.

Students on the Certificate in Data Analytics course at Dublin Business School were already actively engaging with digital platforms during their studies. However they lacked the skills necessary to generate original digital images and digital content. Student learning was facilitated via visual stimulation using examples of abstract art work. Students were invited to actively engage with visual experimentation by designing abstract art pieces using Microsoft PowerPoint. Students' engagement was further enhanced as the group curated a photographic showcase both online and as an exhibited installation in the foyer of the Dublin Business School campus (Aungier Street).

Learning outcomes:

- $\quad$ Collaborative learning.

- $\quad$ Active learning

- $\quad$ Problem solving skills

- $\quad$ Exhibition of work

- $\quad$ Aesthetic

- Performance

- Digital curation

- Digital image manipulation

- Digital and technical proficiency: file extensions, file resizing, sharing documents on the cloud using Google Drive.

Figure 8: Abstract Art exhibition at Dublin Business School

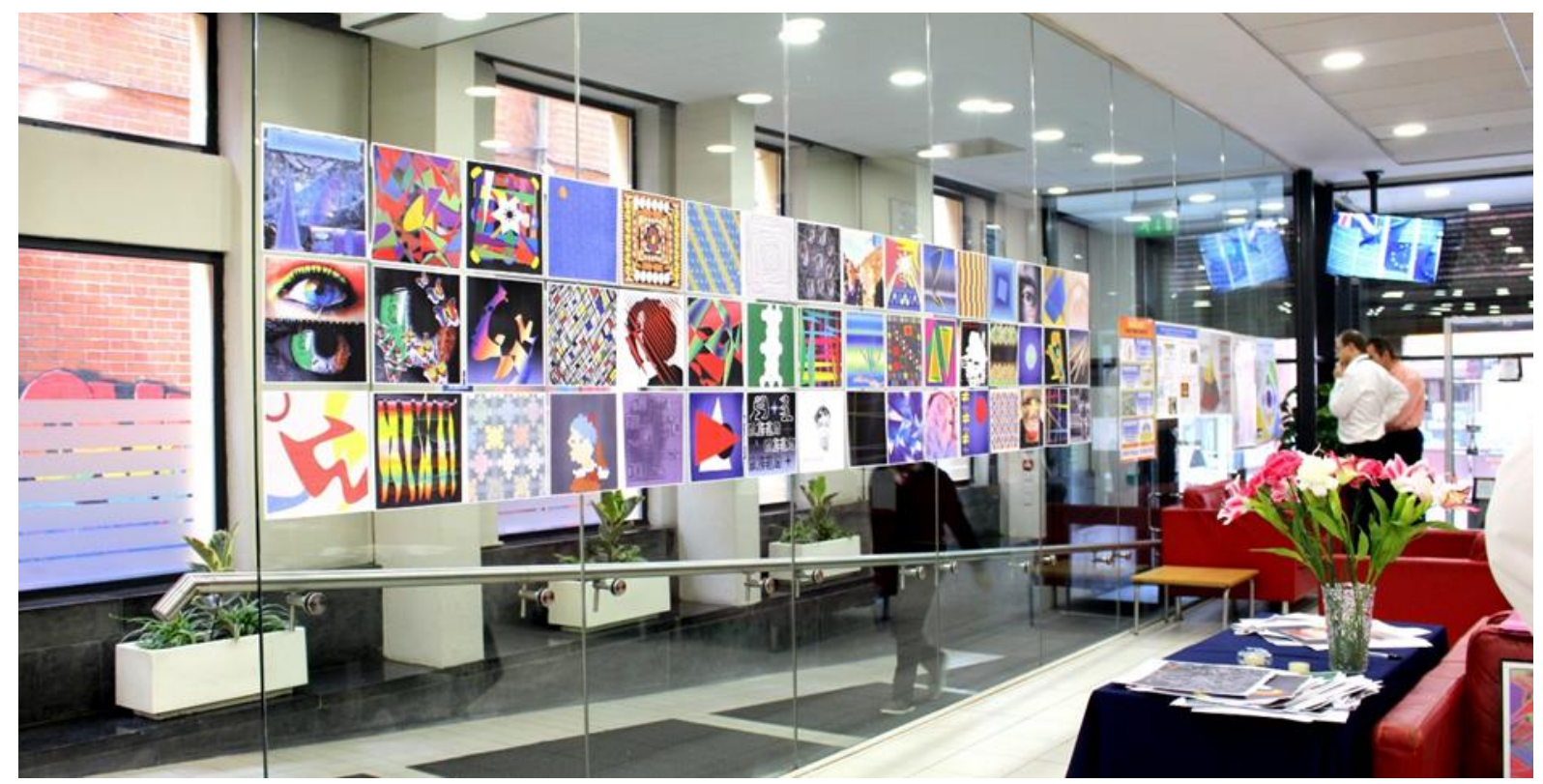




\section{Susan Sweeney and David Hughes}

Figure 9: Abstract art images made with Microsoft PowerPoint (Data analytics students at Dublin Business School)
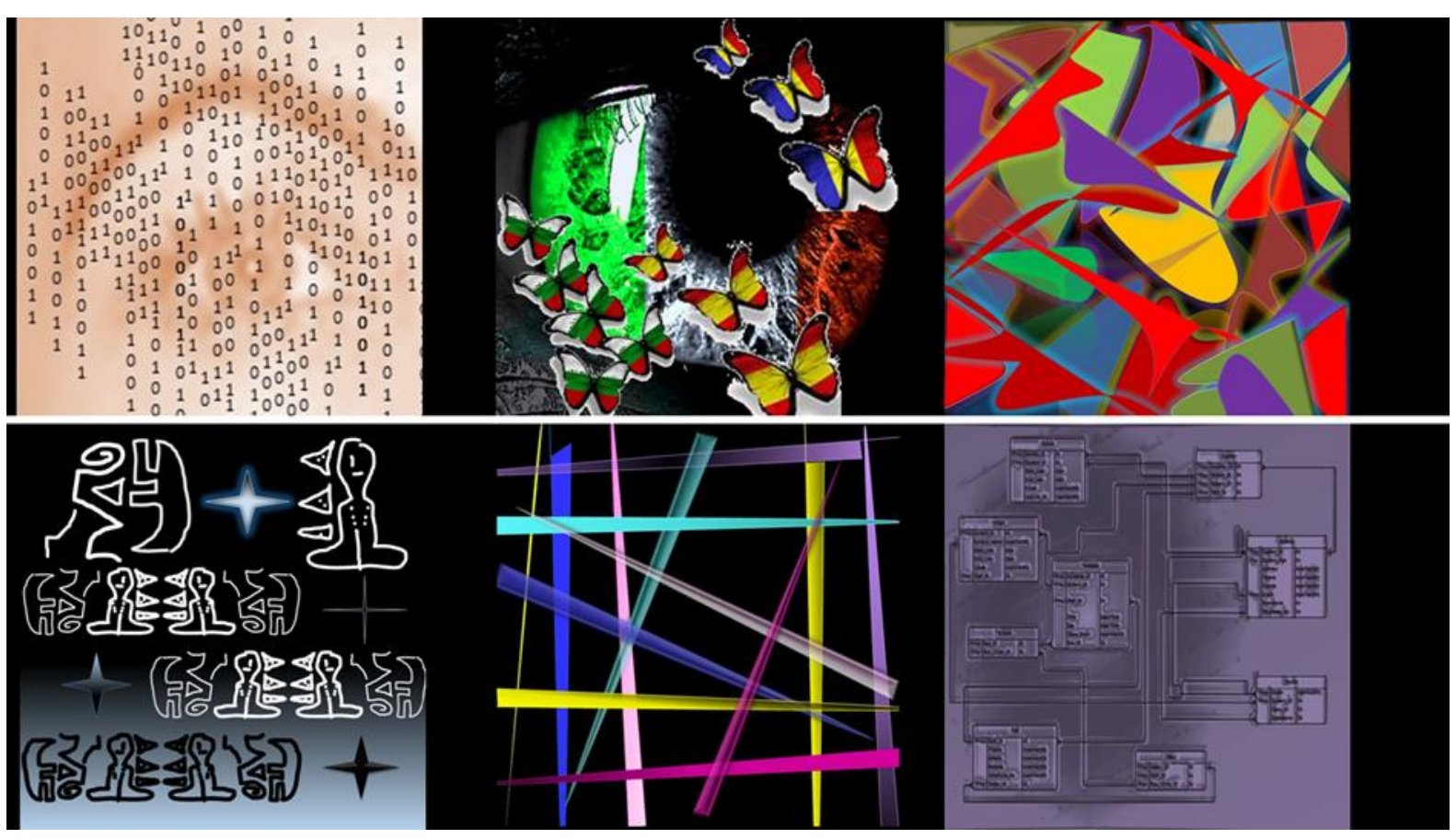

Figure 10: Abstract art images made with Microsoft PowerPoint (Data analytics students at Dublin Business School)

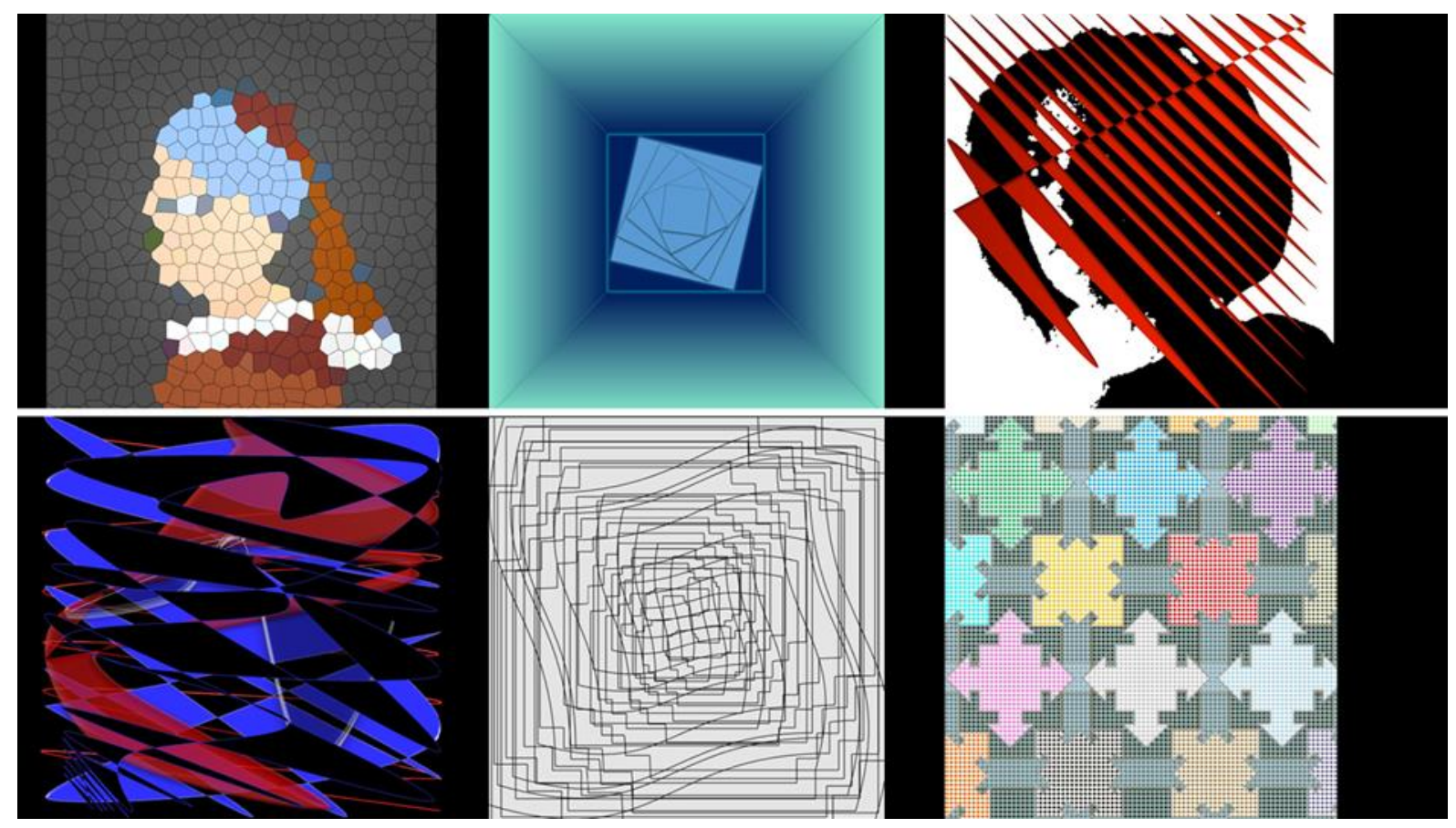




\section{Project 5: Momentum photography exhibition}

Students on the Momentum Diploma in Business programme were invited to take part in a photography exhibition. The role of the lecturer was a key element in this project. Students were brought on various excursions and to exhibition spaces in Dublin city. The first trip was to St Stephen's Green Park where students were asked to reflect on the word 'Momentum' and what it represented to them. Some of the first photographs taken involved the notion of momentum and motion. See Figure 11

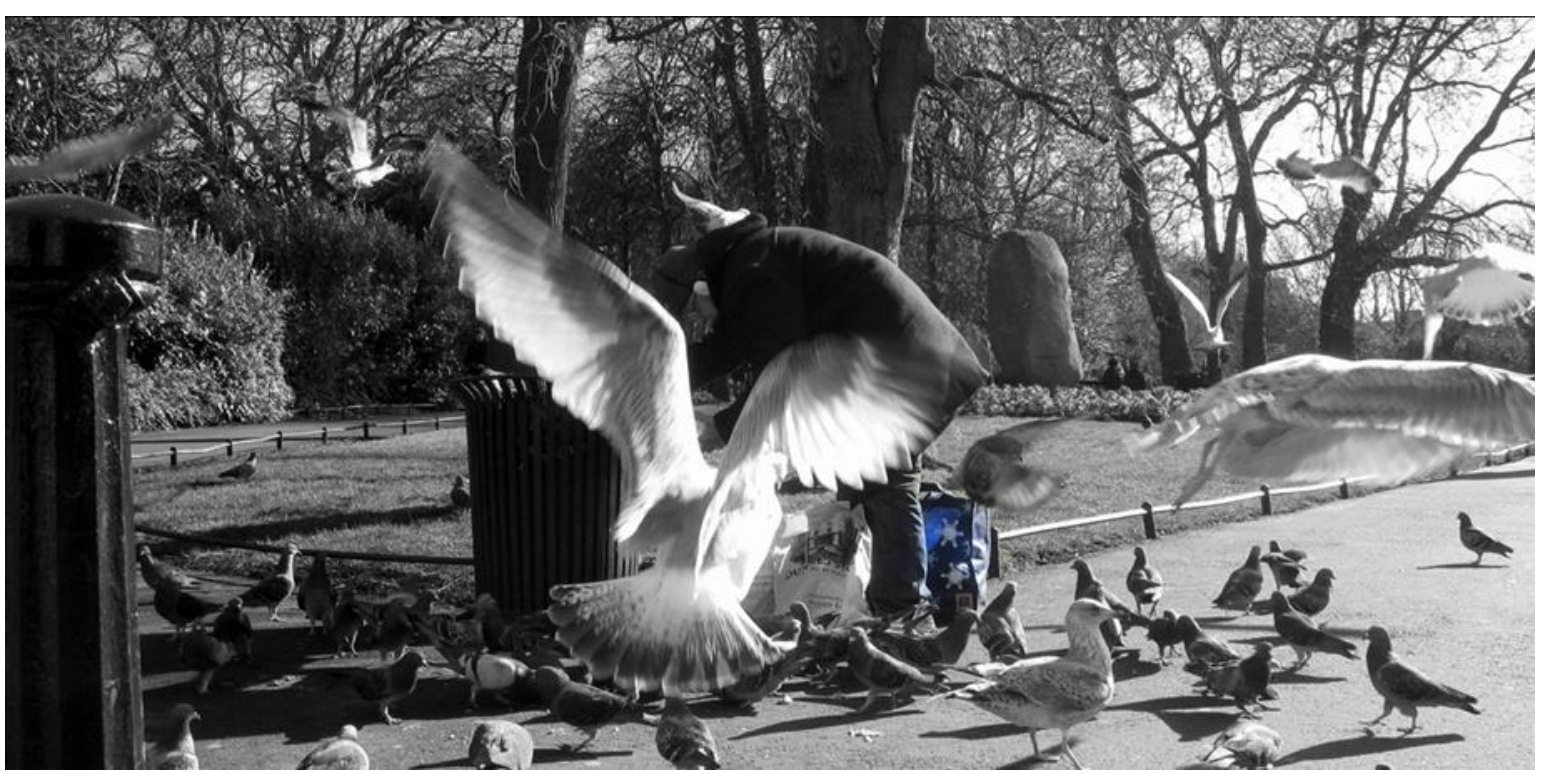

Figure 12: Momentum photography exhibition images. Diploma in Business students

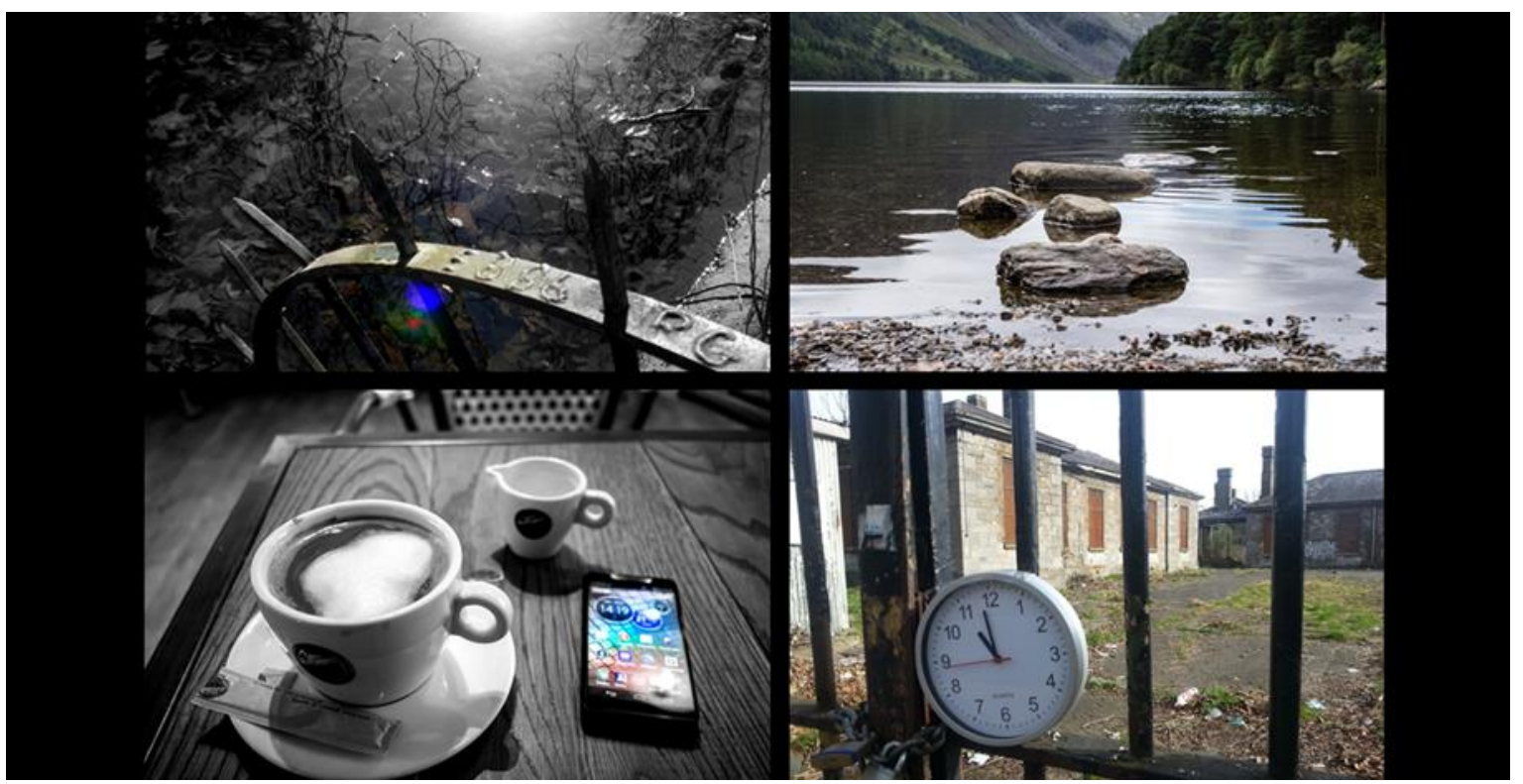


The product produced a diverse range of images. Students also visited the Gallery of Photography. Elements of semiotics, the rule of thirds in photography and visual perception were discussed in the classroom environment. The social constructivist nature of the exhibition and group endeavour was enhanced by an exhibition organised by the Diploma in Business (project management) students and their lecturer. During this exhibition, images were auctioned off to the public in a social media campaign charity event.

Learning outcomes:

- $\quad$ Collaborative learning.

- $\quad$ Active learning

- $\quad$ Problem solving skills

- $\quad$ Exhibition of work

- $\quad$ Aesthetic

- Performance

- Digital curation

- Digital image manipulation

- $\quad$ Project/event management

- $\quad$ Digital and technical proficiency: file extensions, file resizing, sharing documents on the cloud using Google Drive.

Figure 13: Momentum students, Photography exhibition, Filmbase, Dublin

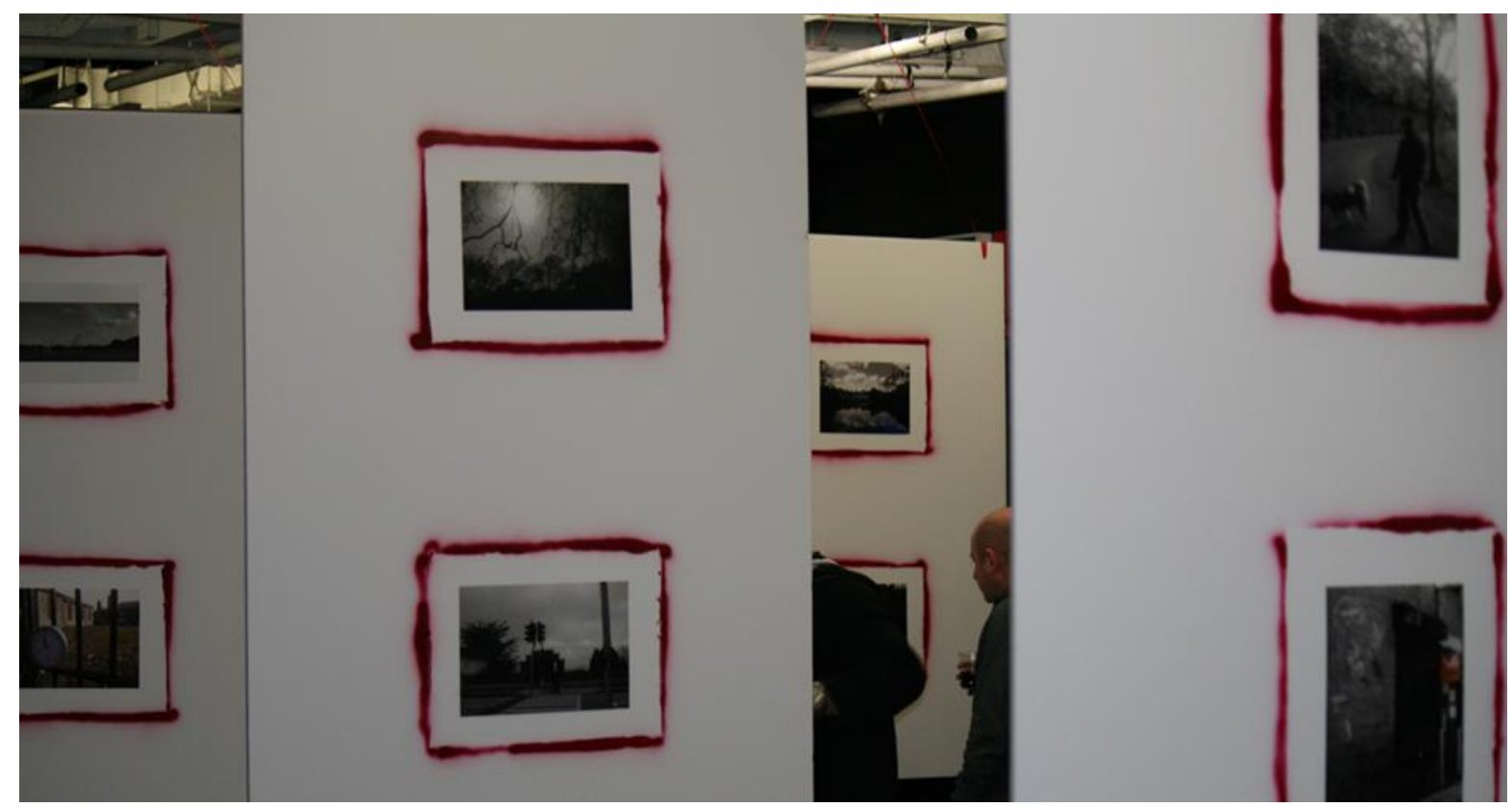

\section{Methodology and limitations to the study}

On completion of the aforementioned visual literacy projects, the lecturer delivering this instruction (one of the authors of this paper) decided to execute some preliminary research. An exploration of the visual literacy literature highlighted a 
dearth of both Irish and social constructivist studies in this area. These gaps in the literature were therefore key stimuli to the writing of this paper.

The research conducted in this paper could only be small scale and preliminary due to a number of factors, the first of which was timing. At the time of deciding to carry out the research, many students had already graduated and left the College. This militated against the use of a qualitative research approach comprising focus groups or interviews as many students were now already out of reach geographically.

The lecturer of the module was still able to reach students via email, however. Pragmatic reasons therefore dictated the use of a quantitative approach using an online survey tool created in Survey Monkey. Open-ended as well as closed-ended questions were also included to elicit some qualitative feedback. Blummer (2015), in a literature review of visual literacy initiatives in academia, found that the majority of visual literacy training projects were small pilots. This is also the case at DBS. There is not yet the scale of delivery to inform a larger study.

A total of 101 students were invited to participate in the survey. These comprised:

1. 67 students from the Momentum Business Diploma programme.

2. 20 students were from the Arts programme, BA Journalism and Media and BA Film and Media

3. 14 students on the Higher Diploma in Business (level 8) were invited to take Part

45 students (44 percent) responded (only six were from journalism, media and film). The majority of respondents were from the business curriculum. The visual literacy lecturer had decided to include students from journalism, film and media by way of attempting to glean some comparative information with students who are expected to have higher levels of visual literacy. It could be argued that the inclusion of students from a film, media and journalism programmes could skew the findings. They did not respond in large numbers however.

\section{Results}

\section{The benefits of visual literacy training for the learner}

Although the sample size is small, initial results are encouraging with the vast majority of students (98\%) agreeing that visual literacy defined in the survey as "having the skillset to source, create or manipulate visual images to get your message across" is an important workplace skill.

The visual exercises undertaken within their lectures boosted students' selfassessment of their image manipulation skills with $66 \%$ of respondents perceiving they have good image manipulation skills, compared to $40 \%$ before the exercises commenced. The exercises also improved students' visual manipulation skills $(72 \%$ of respondents), technical/IT skills (56\% of respondents) and workplace confidence $(56 \%)$. 
The exercises were considered useful, with all bar one student learning something about image design and manipulation. Nearly two-thirds of respondents stated that they learned about technical tools, while nearly half stated they learned something about aesthetics.

Figure 14: The benefits of visual literacy training at $D B S$

\begin{tabular}{|c|c|c|}
\hline Visual Skills Questionnaire 2017 & & key \\
\hline Answer Choices & Responses & \\
\hline Improved your visual manipulation skills & $72.09 \%$ & 31 \\
\hline Imoproved your technical/ IT skills & $55.81 \%$ & 24 \\
\hline Increased your confidence in the workplace & $55.81 \%$ & 24 \\
\hline Inspired you to undetake further study & $16.28 \%$ & 7 \\
\hline Other (please specify) & $18.60 \%$ & 8 \\
\hline
\end{tabular}

\section{The benefits of visual literacy training for employability}

$87 \%$ of respondents believe that visual literacy training enhances the attractiveness of graduates to employers with $56 \%$ of respondents also stating that the visual skills they acquired during their courses had been of value to their employers. It is important to note that over one-third of respondents were still in full time study when they completed the survey. One respondent commented that the exercise may help in their career:

"It helped me understand a lot about visual design and how it can be very useful for my future career"

Students also noted the benefit of the exhibition element of the projects:

"PowerPoint presentation in the Aungier St foyer was useful because that skill I could use on my current job when I did marketing of our services for potential clients"

One respondent noted that:

"We are part of a time of a digital transformation and having the digital tools will only enhance my future job prospects"

Other respondents commented that:

"I have gained experience in imaging and how to create a better piece of work visually and aesthetically"

"It helped a lot; I put together presentations in work so my standard of work is better than before" 
Another respondent commented that:

"It made me appreciate exhibitions more knowing all of the time and effort to put in just to make an event successful. Knowing that one of my works produced for college was exhibited gives me more confidence to say that my work was showcased to the public. I am proud to say that on my social media accounts as well as in a job interview ".

\section{Technical Platforms}

There was a clear preference for PowerPoint as the most useful tool for creating and showcasing images. Responses showed that students were unaware of the image manipulation capabilities of PowerPoint. Several students remarked:

"I conduct group training and present presentation using PowerPoint multiple times per week, preparing them using the skills learned in DBS"

"I was so used to other advanced software that I never knew PowerPoint was actually very useful for many different reasons"

"That so many useful visual design features are pre-included in PowerPoint"

"I feel the most useful tool for creating and showcasing visuals was PowerPoint"

"I personally still believe that Photoshop is the best. But using power point for cropping is ingenious"

PowerPoint was also considered easy to use, with only four students stating that using PowerPoint was the most challenging aspect of the visual exercises that they undertook.

\section{The learning experience}

Qualitative responses from students indicated that students really enjoyed the visual literacy component of their studies at DBS.

"I really enjoyed taking this module. I learned a lot about visual literacy and the important role it plays in today's society"

Students also noted an improvement in their levels of self-confidence and belief. This was a particularly valuable output for Momentum students, many of whom were unemployed. The idea behind the Momentum programme was to reskill unemployed people for the modern workplace. One student commented:

"Thought it was a great idea, sense of achievement having a picture in the gallery and charity ....all while being unemployed"

Some students who undertook the visual literacy exercises felt encouraged to further their knowledge and skills in this area:

"Although I came to study Data Management and Analytics, you have won me over into the field of Digital media with a focus around Digital Design and Web Development. You really inspired me a lot with your course. I have been putting what 
you taught me into practice because I would never want to forget. Your line of specialisation inspired me to be more creative".

\section{Visual Exercises}

In the questionnaire students were invited to comment on their visit to the Gallery of Photography. Some student comments highlight the value of scaffolding assignments as per the Social Constructivist approach (Little, 2015; Hanson and Sinclair 2008). One respondent commented:

"It brought meaning to the class exercises"

The reflective blog element of the Riverwalk project both facilitated reflective writing and the acquisition of a new skill. A respondent commented:

"It was the subject of my first blog post. I learned to reflect on what I experienced and the learning outcomes".

\section{Discussion}

Although small scale in size, the survey findings are consistent with the literature. Flynt and Brozo (2010) cite Ausburn and Ausburn's (1978) potential benefits of visual literacy, which include improvement in the following areas:

1. Self-expression and ordering of ideas

2. Student motivation and interest in a variety of subjects

3. Chances of reaching the disengaged

4. Self-image and relationship to the world

5. Self-reliance, independence, and confidence

Other visual literacy studies actualise these potential benefits. In Griffin et al. (2016) study, dermatology students self-reported an improvement in observational, verbal and written descriptive skills after taking a short visual literacy training course led by an art historian. Art students in Eber \& Wolfe's study (2000) showed better selfexpression and ordering of ideas. In a similar vein, Holland (2014) noted greater understanding and engagement from politics and international relations students after introducing video to his modules, while Bristor and Drake's (1994) longitudinal study of second level students found them to be more positive and self-confident after the introduction of a visual literacy element to a school curriculum .

This paper corroborates the benefits of visual literacy training as outlined in the aforementioned studies. Comments from DBS students would indicate that, subsequent to visual literacy training, these students feel that they can express themselves more coherently and cogently, have more self-reliance, independence and confidence and have a better self-image. This paper also shows the benefits of 
visual literacy in an information technology age such as improved technical skills, knowledge of technical platforms etc., confirming more recent definitions of visual literacy which highlight the importance of being able to create and manipulate as well as interpret and analyse images.

\section{Conclusion and Recommendations}

Although small scale in size, this paper augments the literature on visual literacy education by exploring its practice in an Irish context. Additionally the paper provides information on the social constructivist approach to teaching visual literacy. An interesting finding of the paper is the reported increase in soft as well as technical skills that survey respondents reported. The 10th edition of the Gradlreland report (2017) states that fundamental soft skills are lacking in Irish graduate recruits. Additionally, in terms of hard skills 23 percent of companies surveyed noted that graduates were lacking in knowledge of basic IT systems including Microsoft Office.

The social constructivist nature of the digital visual event curation implemented across all five projects lends itself to enhanced communication skills, IT skills and file management skills using the cloud storage. The presentation and performance element of the exhibition of student work encourages social interaction where students were observed to be proud of their work and which boosted their selfconfidence as a result. Encouraging students to explore even the basic image manipulation functions in PowerPoint provides graduates with a skill that is transferable to the office environment. Graphic design tools and platforms generally involve the acquisition of costly IT packages and the specific skills to use them. PowerPoint, on the other hand, as part of the Microsoft office suite, has a familiar learning convention for students and is immediately accessible in the business and corporate environment. PowerPoint has evolved in recent years and is a powerful graphics tool that can be used for complex 3D animations and 2D image manipulation and reinvention, though has not been much used as an image manipulation tool (Lababede 2004a, 2004b) Engagement with visual literacy exercises adds value to the graduate skill set which in turn benefits the business environment.

Despite the limitations inherent in such a preliminary study, the positive response of the students would indicate that there is a case for rolling out a visual literacy element into other business courses at Dublin Business School on a wider and more formal basis with more extensive input from industry. There may be a need to refine and alter visual literacy projects undertaken as required but this could be done in consultation with employers. This may in turn provide the basis for a larger scale study in the College of visual literacy education using both quantitative and qualitative methods, incorporating interviews and focus groups as well as a survey. Future research on visual literacy could also explore the perceptions of visual literacy training by employers along with an analysis of their perceived requirements in this area. 


\section{References}

Ali-Khan, C. (2011) 'Seeing what we mean: visual knowledge and critical epistemology', International Journal of Qualitative Studies in Education, 24(3), pp. 303-322.

Alpan, G.B. (2015) 'The reflections of visual literacy training in pre-service teachers' perceptions and instructional materials design', Journal of Education and Human Development, 4(2), p.143-157.

Andrews, D.C. (2016) 'Making the familiar strange: thinking visually in a study abroad course in professional communication', Business and Professional Communication Quarterly, 79(1), pp. 6-27.

Association of College and Research Libraries (2011) 'ACRL visual literacy competency standards for higher education', American Library Association (October 2011). Available at: http://www.ala.org/acrl/standards/visualliteracy . (Accessed: 28 March 2017).

Avgerinou, M. (2009) 'Re-viewing visual literacy in the "bain d'images" era', Techtrends, 53(2), pp. 28-34.

Baker, W.H. (2006) 'Visual communication: integrating visual instruction into business communication courses', Business Communication Quarterly, 69(4), pp. 403-407.

Bamford, A. (2003) 'The visual literacy white paper'. Available at: http://wwwimages.adobe.com/content/dam/Adobe/en/education/pdfs/visual-literacy-wp.pdf (Accessed: 2 May 2017).

Barnes, C., Flanagan, B., Corcoran, F. and O’Neill, B. (2007) Final report: critical media literacy in Ireland. Dublin: Radharc Media Trust.

Beaudoin, J.E. (2016) 'Describing images: a case study of visual literacy among library and information science students', College \& Research Libraries, 77(3), pp. 376-392.

Benson, P. J. (1997) 'Problems in picturing text: a study of visual/verbal problem solving', Technical Communication Quarterly, 6 (2), pp. 141-160.

Berger, J. (1973) Ways of seeing. London: British Broadcasting Corporation and Penguin Books.

Bernhardt, S. (1986) 'Seeing the text', College Composition and Communication, 37(1), pp. 66-78.

Bintz, C. (2016) 'Visual literacy: does it enhance leadership abilities required for the twentyfirst century?', Journal of Visual Literacy, 35(2), pp. 91-103.

Bleed, R. (2005) 'Visual literacy in higher education', EDUCAUSE Learning Initiative. Available at:

http://net.educause.edu/ir/library/pdf/eli4001.pdf (Accessed: 11 May 2017).

Blummer, B. (2015) 'Some visual literacy initiatives in academic institutions: a literature review from 1999 to present', Journal of Visual Literacy, 34(1), pp. 1-34.

Bristor, V. and Drake, S. (1994), 'Linking the language arts and content areas through visual technology', T.H.E. Journal, 22(2), pp. 74-77, General OneFile, EBSCOhost [Online]. (Accessed: 11 May 2017). 
Brumberger, E.R. (2005) 'Visual rhetoric in the curriculum: pedagogy for a multimodal workplace', Business Communication Quarterly, 68(3), pp. 318-333. Business Source Complete, EBSCOhost [Online]. (Accessed: 4 April 2017).

Brumberger, E.R. (2011) 'Visual literacy and the digital native: an examination of the millennial learner', Journal of Visual Literacy, 30 (1), pp. 19-47.

Butler, A. (2013) 'Beyond the moment photographed: from visual to text', Irish Teachers Journal, 1(1) pp. 100-114.

Chanlin, L. (1998) 'Animation to teach students of different knowledge levels', Journal of Instructional Psychology, 25(3), pp.166-175.

Cook, E., Teaff, E. and Cook, L. (2015) 'A collaborative vision: partnering with STEM faculty to teach visual literacy through multimedia research presentations', Internet Reference Services Quarterly, 20, 3/4, pp. 63-88, Library \& Information Science Source, EBSCOhost [Online]. (Accessed: 3 April 2017).

Daly, T. (2015) 'Digital literacy: access, participation and communication for the 'non-literate' in the new digital age', LEARN, Journal of the Irish Learning Support Association, 3, pp. 115137 ,

Danos, X. (2014) Graphicacy and culture: refocusing on visual learning. Loughborough: Loughborough Design Press Ltd.

Debes, J. (1968) 'Some foundations of visual literacy', Audio Visual Instruction, 13, pp. 961964.

Dinham, J., Grushka, K., MacCallum, J., Pascoe, R., Wright, P. and Brown, N. (2007) 'Visual education - repositioning visual arts and design: educating for expression and participation in an increasingly visually-mediated world', International Journal of Learning, 14(6), pp. 7785.

Eber, D. and Wolfe, R. (2000) 'Teaching computer graphics visual literacy to art and computer science students: advantages, resources and opportunities', ACM SIGGRAPH Computer Graphics, 34(2), pp. 22-24.

Emanuel, R. and Challons-Lipton, S. (2013) 'Visual literacy and the digital native: another look', Journal of Visual Literacy, 32 (1), pp. 7-26, Academic OneFile, EBSCOhost [Online]. (Accessed: 24 March 2017).

ENViL (2014) 'Towards a common European framework of reference for visual literacy'. Available at:

http://envil.eu/en. (Accessed: 25 March 2017).

Ernst, H., McGahan, W. and Harrison, J. (2015) 'Questionable benefit of visual and peer mediated learning on overall learning outcomes of a first-year physiology course', International Journal of Mobile And Blended Learning, 7(1), pp. 25-40, ERIC, EBSCOhost [Online]. (Accessed: 31 March 2017).

Fabian, C.A. (2005) 'Teaching the teachers: expanding the pedagogical role of the visual resources professional', Visual Resources Association Bulletin, 32(2) pp. 77-80.

Felten, P. (2008) 'Visual literacy', Change: The Magazine of Higher Learning, 40(6), pp. 6064. 
Finley, R. (2014) 'Common core in action: 10 visual literacy strategies'. Available at: https://www.edutopia.org/blog/ccia-10-visual-literacy-strategies-todd-finley (Accessed: 28 March 2017).

Flynt, E. and Brozo, W. (2010) 'Visual literacy and the content classroom: a question of now, not when', The Reading Teacher, 63(6), pp. 526-528.

Gradlreland (2017) Graduate salary and graduate recruitment trends survey 2017. Dublin: Gradlreland.

Griffin, L., Chiang, N., Tomlin, H., Young, H. and Griffiths, C. (2016) 'A visual literacy course for dermatology trainees', The British Journal of Dermatology, 177(1), pp. 310-311.

MEDLINE, EBSCOhost [Online]. (Accessed: 3 April 2017).

Hanson, J.M. and Sinclair, K.E. (2008) 'Social constructivist teaching methods in Australian universities - reported uptake and perceived learning effects: a survey of lecturers', Higher Education Research \& Development, 27(3), pp. 169-186.

Hattwig, D., Bussert, K., Medaille, A. and Burgess, J. (2013) 'Visual literacy standards in higher education: new opportunities for libraries and student learning', portal: Libraries and the Academy, 13(1), pp. 61-89.

Heinich, R., Molenda, M., Russell, J. D. and Smaldino, S. E. (1999) Instructional media and technologies for learning. $6^{\text {th }}$ edn. Upper Saddle River, NJ: Prentice-Hall.

Holland, J. (2014) 'Video use and the student learning experience in politics and international relations', Politics, 34(3), pp. 263-274.

Holland, J., O'Sullivan, R. and Arnett, R. (2015) 'Is a picture worth a thousand words: an analysis of the difficulty and discrimination parameters of illustrated vs. text-alone vignettes in histology multiple choice questions', BMC Medical Education, 15(1), p.184.

Hollman, V. (2014) 'Promoting visual literacy among undergraduate students in geography: teaching a visualized Latin America', Journal of Geography in Higher Education, 38(1), pp. 136-147. Available at: https://search.proquest.com/docview/1504640539?accountid=149453 (Accessed: 28 March 2017).

Johnson, L. (2006) 'The sea change before us', Educause Review, 41(2), pp.72-73.

Kostelnick, C. (1988) 'A systematic approach to visual language in business communication', Journal of Business Communication, 25(3), pp. 29-48.

Lababede, O. (2004a) 'Digital image editing using PowerPoint: part 1, introduction to the image-manipulation commands', American Journal of Roentgenology, 183(3), pp. 847-851.

Lababede, O. (2004b) 'Digital image editing using PowerPoint: part 2, practical applications of the image-manipulation commands', American Journal of Roentgenology, 183(3), pp. 853858.

Little, D., Felten, P., and Berry, C. (2015) 'Teaching visual literacy across the curriculum: suggestions and strategies', New Directions for Teaching and Learning, 141, pp. 87-90. Academic OneFile, EBSCOhost [Online]. (Accessed: 28 March 2017).

Lopatovska, I., Hatoum, S., Waterstraut, S., Novak, L. and Sheer, S. (2016) 'Not just a pretty picture: visual literacy education through art for young children', Journal of Documentation, 72(6), pp. 1197-1227. 
Metros, S.E. (2008) 'The educator's role in preparing visually literate learners', Theory into Practice, 47(2), pp.102-109.

Mbelani, M. (2008) 'Winds of change in teachers' classroom assessment practice: A selfcritical reflection on the teaching and learning of visual literacy in a rural Eastern Cape High School', English Teaching, 7(3), pp. 100-114.

Milkova, L., Crossman, C., Wiles, S. and Allen, T. (2013) Engagement and skill development in biology students through analysis of art', CBE Life Science Education, 12(4), pp. 687-700.

Naghshineh, S., Hafler, J.P., Miller, A.R., Blanco, M.A., Lipsitz, S.R., Dubroff, R.P., Khoshbin, S. and Katz, J.T. (2008) 'Formal art observation training improves medical students' visual diagnostic skills', Journal of General Internal Medicine, 23(7), pp. 991-997.

New Media Consortium (2005) 'A global imperative: the report of the 21st century literacy summit'. Available at:

http://files.eric.ed.gov/fulltext/ED505105.pdf (Accessed: 28 March 2017).

Papworth, R. (2016) 'A multi-disciplinary, social constructivist approach to promoting student engagement, retention and achievement in higher education', Dialogue (1311-9206), 3, pp. 52-68. Business Source Complete, EBSCOhost [Online]. (Accessed: 13 July 2017).

Pauwels, L. (2008) 'Visual literacy and visual culture: reflections on developing more varied and explicit visual competencies', The Open Communication Journal, 2, pp. 79-85.

Piaget, J. (2002) The Language and thought of the child. $3^{\text {rd }}$ edn. London: Routledge Classics.

Rosenquist, C. (2012) 'visual form, ethics, and a typology of purpose: teaching effective information design', Business Communication Quarterly, 75(1), pp. 45-60. Business Source Complete, EBSCOhost. [Online]. (Accessed: 4 April 2017).

Schultz, B. (2006) 'Business documents don't have to be boring', Business Communication Quarterly, 69(4), pp. 407-410. Business Source Complete, EBSCOhost. [Online]. (Accessed: 4 April 2017).

Seery, N., Lynch, R. and Dunbar, R. (2011) 'A review of the nature, provision, and progression of graphical education in Ireland' in Norman, E.W.L. and Seery, N. (eds.) IDATER online conference: graphicacy and modelling 2010. Loughborough: Design Education Research Group, Loughborough Design School.

Silverman, K.N. and Piedmont, J. (2016) 'Reading the big picture: a visual literacy curriculum for today', Knowledge Quest, 44(5), pp. 32-37.

Siu-Kay, P. (2010) 'Visual language skills: do business students need them', Global Journal Of Business Research, 4(2), pp. 85-96.

Stafford, T. (2011) Teaching visual literacy in the primary classroom: comic books, film, television and picture narratives. Abingdon, Oxon, England: Routledge, eBook Index, EBSCOhost [Online]. Available at:

http://search.ebscohost.com/login.aspx?direct=true\&AuthType=ip, shib,cookie,url\&db=edseb k\&AN=328128\&site=eds-live (Accessed: 28 March 2017).

Stokes, S. (2001) 'Visual literacy in teaching and learning: a literature perspective', Electronic Journal for the Integration of Technology in Education, 1(1), pp. 10-19. 
Story, L. (2007) 'Anywhere the eye can see, it's now likely to see an ad', New York Times, 15 January. Available at:

https://search.proquest.com/docview/433494552?accountid=149453 (Accessed: 28 March 2017).

Sweeney-Burt, N. (2014) 'Implementing digital storytelling as a technology integration approach with primary school children', Irish Journal of Academic Practice, 3(1). Available at: http://arrow.dit.ie/ijap/vol3/iss1/4 (Accessed: 28 March 2017).

Toth, C. (2013) 'Revisiting a genre: teaching infographics in business and professional communication courses', Business Communication Quarterly, 76(4), pp. 446-457.

Vygotsky, L. S. (1978) Mind in society: development of higher psychological processes. Cambridge, MA: Harvard University Press.

White, C., Breslow, L. and Hastings, D. (2015) 'Exploring visual literacy as a global competency: an international study of the teaching and learning of communication', Proceedings of 2015 International Conference on Interactive Collaborative Learning (ICL), 20-24 September. Florence: IEEE, pp. 771-778.

Wileman, R.E. (1993) Visual communicating. Englewood Cliffs, N.J.: Educational Technology Publications.

Wilhelm, L. (2005) 'Increasing visual literacy skills with digital imagery: successful models for using a set of digital cameras in a college of education', T.H.E. Journal, 32(7), pp. 24-27. Available at:

https://search.proquest.com/docview/214817211?accountid=149453 (Accessed: 28 March 2017).

Yenawine, P. (1997) 'Thoughts on visual literacy', in Flood, J., Health, S. and Lapp, D. (eds.) Handbook of research on teaching literacy through the communicative and visual arts. London: Taylor \& Francis.

Young, J. and Ruediger, C. (2016) 'Incorporating visual literacy standards in an introductory statistics course'. Available at:

http://www.statlit.org/pdf/2016-Young-Ruediger-ASA.pdf (Accessed: 28 March 2017).

Zambo, D.M. (2009) 'Using visual literacy to help adolescents understand how images influence their lives', Teaching Exceptional Children, 41(6), pp. 60-67. 
Q1 Please indicate programme of study that you completed whilist at DBS

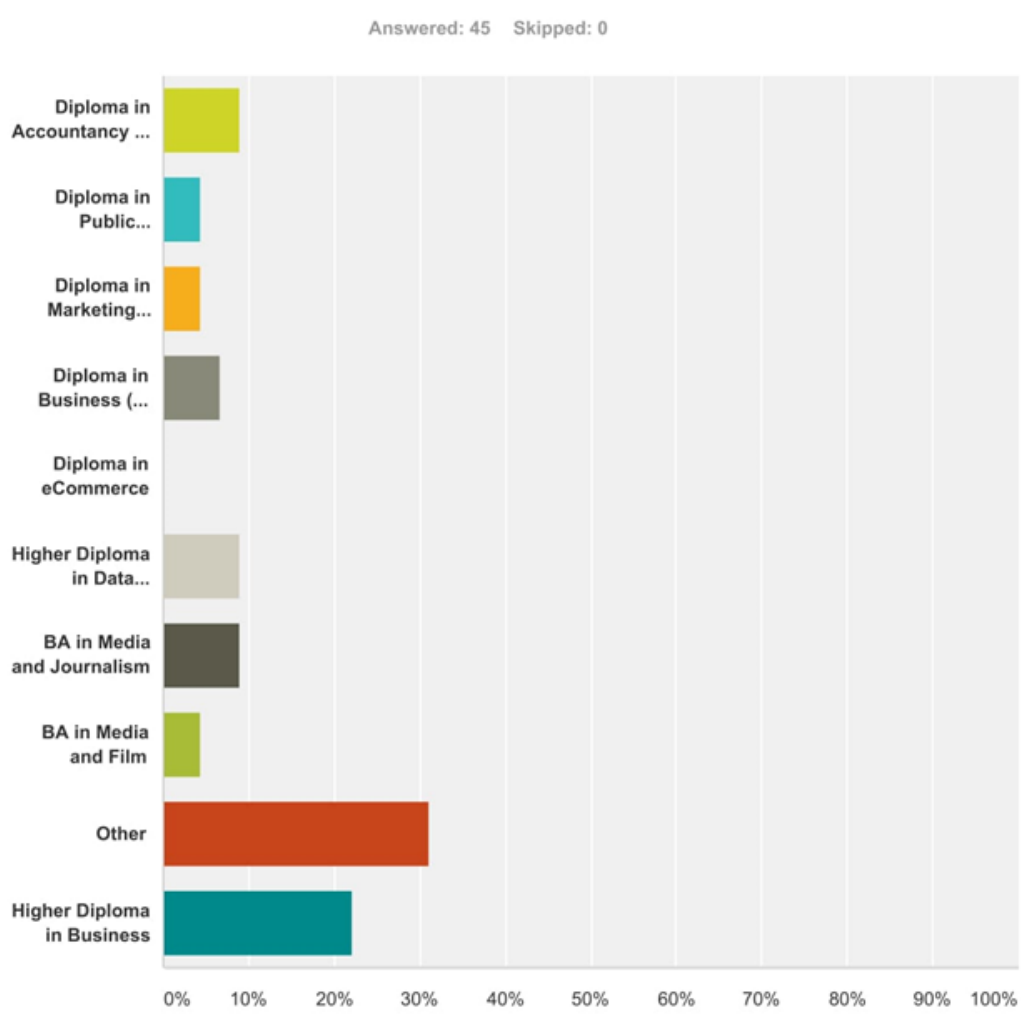

\begin{tabular}{l|c}
\hline Answer Choices & Responses \\
\hline Diploma in Accountancy and Finance (Momentum) & $\mathbf{8 . 8 9 \%}$ \\
\hline Diploma in Public Relations (Momentum) & $4.44 \%$ \\
\hline Diploma in Marketing (Momentum) & $4.44 \%$ \\
\hline Diploma in Business ( Momentum) & 2 \\
\hline Diploma in eCommerce & $\mathbf{6 . 6 7 \%}$ \\
\hline Higher Diploma in Data Management and Analytics, Information Technology (Springboard) & $\mathbf{0 . 0 0 \%}$ \\
\hline BA in Media and Journalism & $\mathbf{8 . 8 9 \%}$ \\
\hline BA in Media and Film & $\mathbf{3 . 8 9 \%}$ \\
\hline Other & 4 \\
\hline Higher Diploma in Business & $4.44 \%$ \\
\hline Total & $\mathbf{3 1 . 1 1 \%}$ \\
\hline
\end{tabular}

Q2 Do you think that having the skillset to source, create or manipulate visual images 
to get your message across is an important skill in the workplace today?

Answered: 45 Skipped: 0

Yes

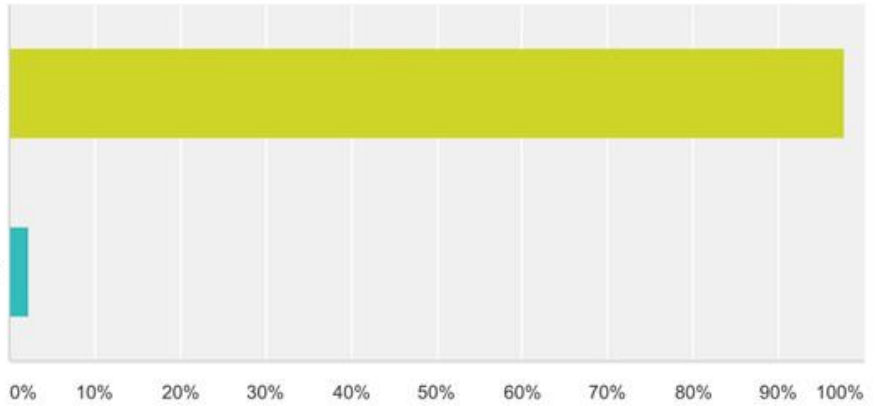

\begin{tabular}{|c|c|c|}
\hline Answer Choices & Response & \\
\hline Yes & $97.78 \%$ & 44 \\
\hline No & $2.22 \%$ & 1 \\
\hline Total & & 45 \\
\hline
\end{tabular}

Q3 Please rate your competency with image manipulation prior to your studies at DBS on a scale of 1-5 with five being the most important or highest value. Please tick the box

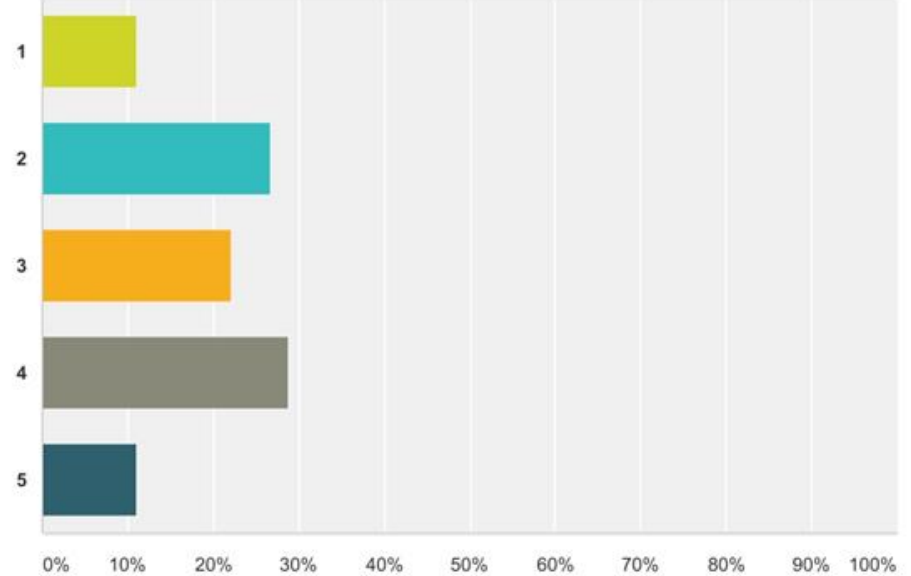

\begin{tabular}{|c|l|l|}
\hline Answer Choices & Responses & 5 \\
\hline 1 & $\mathbf{1 1 . 1 1 \%}$ & $\mathbf{2 6 . 6 7 \%}$ \\
\hline 2 & & 12
\end{tabular}




\begin{tabular}{c|cc}
\hline 3 & $22.22 \%$ & 10 \\
\hline 4 & $28.89 \%$ & 13 \\
\hline 5 & $11.11 \%$ & 5 \\
\hline Total Respondents: 45 & & \\
\hline
\end{tabular}

Q4 Which of the following visual exercises did you engage in whilst studying at DBS?

Please select ONE or MORE more of the following?

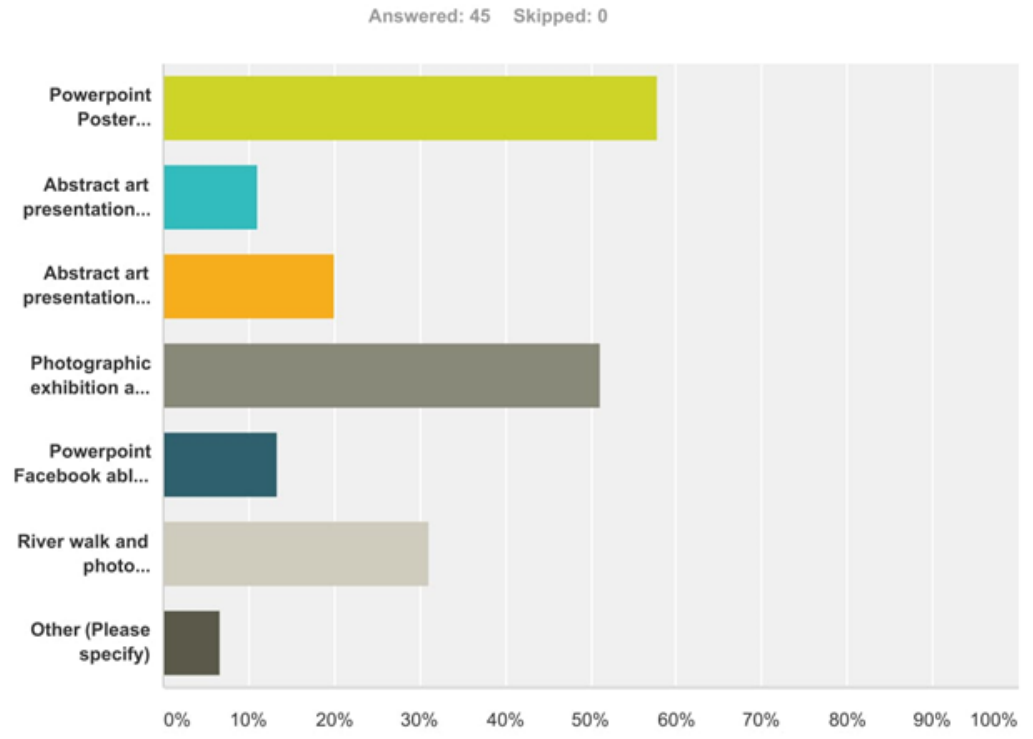

\begin{tabular}{l|c}
\hline Answer Choices & \multicolumn{1}{|c}{ Responses } \\
\hline Powerpoint Poster presentation in Aungier Street foyer & $\mathbf{5 7 . 7 8 \%}$ \\
\hline Abstract art presentation Aungier Street foyer & $\mathbf{1 1 . 1 1 \%}$ \\
\hline Abstract art presentation in Castle House & $\mathbf{2 0 . 0 0 \%}$ \\
\hline Photographic exhibition at Filmbase & $\mathbf{5 1 . 1 1 \%}$ \\
\hline Powerpoint Facebook ablum cover installation at FilmBase & $\mathbf{1 3 . 3 3 \%}$ \\
\hline River walk and photo exhibition in Filmbase & $\mathbf{3 1 . 1 1 \%}$ \\
\hline Other (Please specify) & $\mathbf{6 . 6 7 \%}$ \\
\hline Total Respondents: 45 & 14 \\
\hline
\end{tabular}

Q5 What do you feel you learned about visual image design and image manipulation during the visual exercises?

Please select ONE or MORE of the following. 


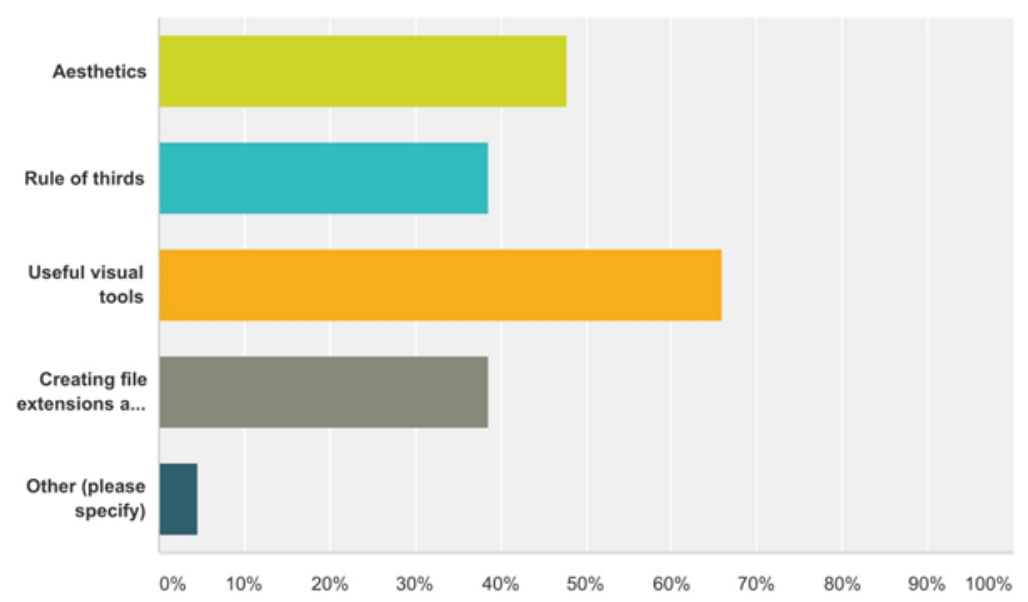

\begin{tabular}{|l|c}
\hline Answer Choices & Responses \\
\hline Aesthetics & $47.73 \%$ \\
\hline Rule of thirds & $38.64 \%$ \\
\hline Useful visual tools & $65.91 \%$ \\
\hline Creating file extensions and other IT skills (jpg, png, pptx conversions) & $38.64 \%$ \\
\hline Other (please specify) & $4.55 \%$ \\
\hline Total Respondents: 44 & 29 \\
\hline
\end{tabular}

Q6 What do you feel was the most useful tool(s) for creating and showcasing visuals?

Answered: 34 Skipped: 11

Q7 What did you find challenging about the visual exercises that you undertook?

Answered: 33 Skipped: 12

Q8 Please rate your competency with image manipulation after completing the visual exercises on your programme from a scale of 1-5 with five being the most important. 


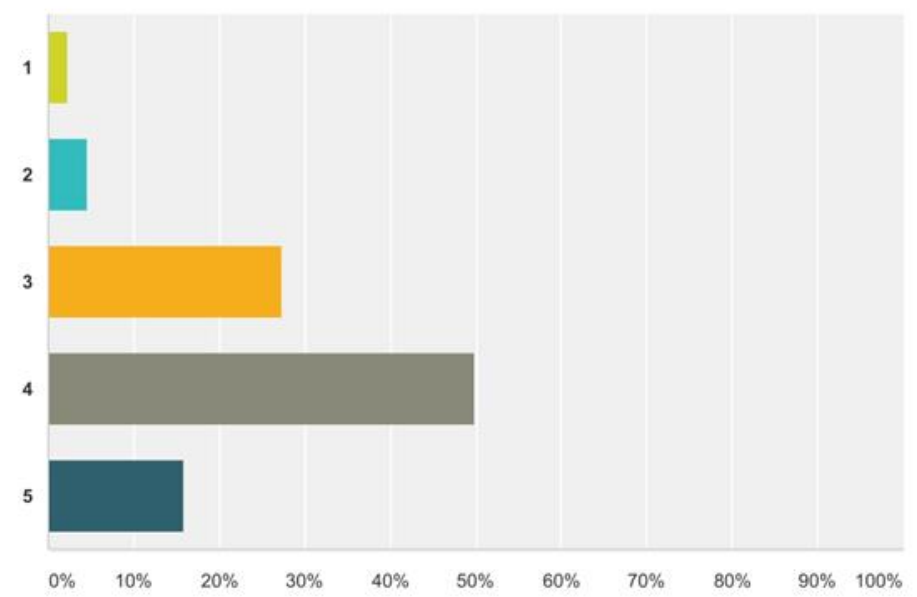

\begin{tabular}{r|lr}
\hline Answer Choices & Responses & 1 \\
\hline 1 & $2.27 \%$ & 2 \\
\hline 2 & $4.55 \%$ & 12 \\
\hline 3 & $27.27 \%$ & 22 \\
\hline 4 & $50.00 \%$ & 7 \\
\hline 5 & $15.91 \%$ & 44 \\
\hline Total & & \\
\hline
\end{tabular}

Q9 Did you feel that there were any other benefits to completing visual exercises as part of your programme? Please select ONE or MORE of the following.

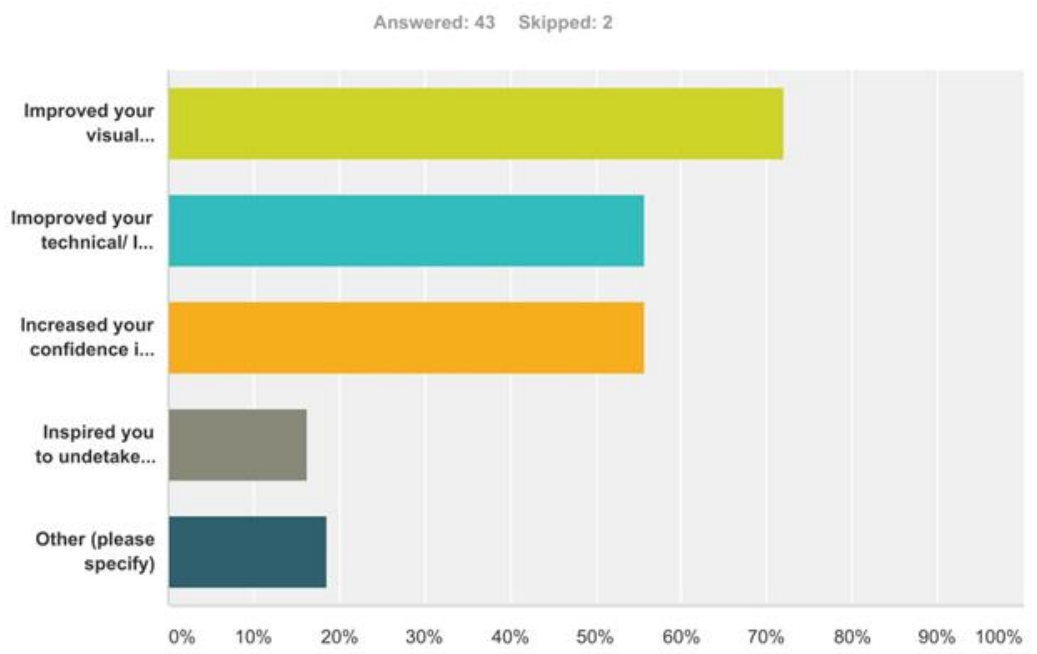




\begin{tabular}{|l|l|}
\hline Answer Choices & Responses \\
\hline Improved your visual manipulation skills & $72.09 \%$ \\
\hline Imoproved your technical/ IT skills & $\mathbf{5 5 . 8 1 \%}$ \\
\hline Increased your confidence in the workplace & $\mathbf{5 5 . 8 1 \%}$ \\
\hline Inspired you to undetake further study & $16.28 \%$ \\
\hline Other (please specify) & $\mathbf{1 8 . 6 0 \%}$ \\
\hline Total Respondents: 43 & 24 \\
\hline
\end{tabular}

Q10 If you are currently in a programme of further study or completed one since leaving DBS please could you indicate what this programme of study is?

Answered: 24 Skipped: 21

Q11 Do you feel that the visual skills that you acquired at DBS have been of value to your employer?

Answered: 43 Skipped: 2

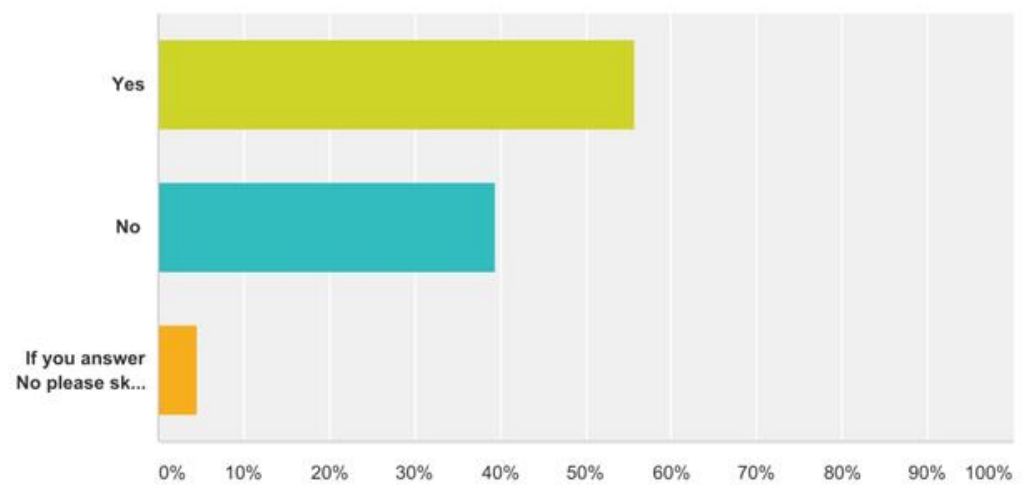

\begin{tabular}{|l|l|}
\hline Answer Choices & \multicolumn{1}{|l|}{ Responses } \\
\hline Yes & $55.81 \%$ \\
\hline No & $39.53 \%$ \\
\hline If you answer No please skip to question 13 & $4.65 \%$ \\
\hline Total & 17 \\
\hline
\end{tabular}

Q12 Please describe the way in which your visual skills were used in the workplace and what tools/platforms you use most. 
Q13 Do you think that visual training enhances the attractiveness of graduates to employers?

Answered: 45 Skipped: 0

Yes

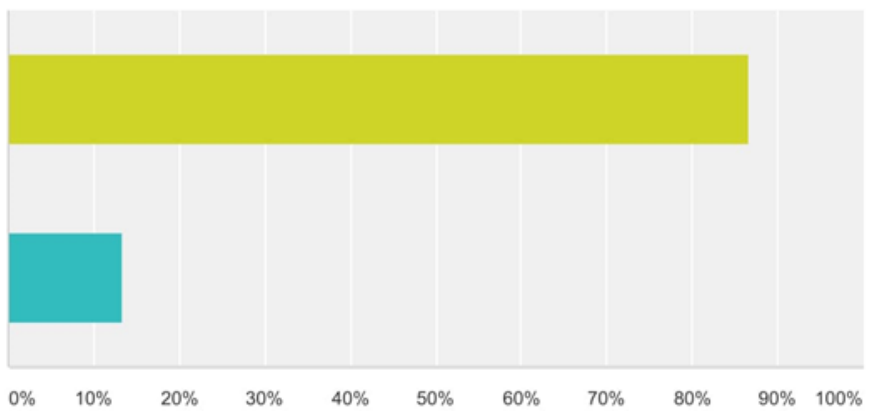

\begin{tabular}{|c|c|c|}
\hline Answer Choices & Respon & \\
\hline & $86.67 \%$ & 39 \\
\hline Yes & & \\
\hline No & $13.33 \%$ & 6 \\
\hline Total & & 45 \\
\hline
\end{tabular}

Q14 If you feel that visual training enhances the attractiveness of graduates to employers, please indicate why?

Answered: 33 Skipped: 12

Q15 Do you have suggestions for inclusion in future visual exercises on DBS programmes?

Answered: 27 Skipped: 18

Q16 Did you visit the Gallery of Photography with Susan?

Answered: 45 Skipped: 0 


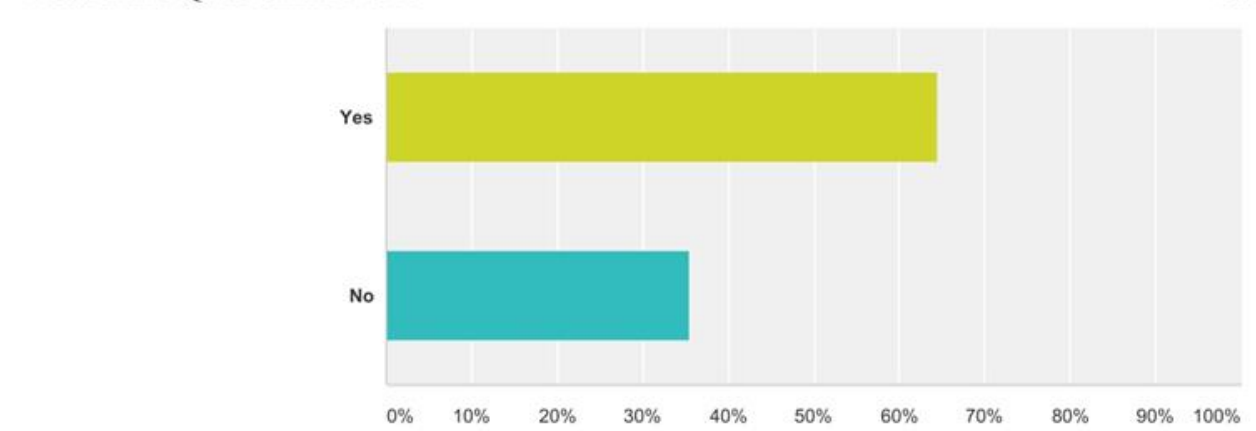

\begin{tabular}{|c|c|c|}
\hline Answer Choices & Responses & \\
\hline Yes & $64.44 \%$ & 29 \\
\hline No & $35.56 \%$ & 16 \\
\hline Total & & 45 \\
\hline
\end{tabular}

Q17 If you answered 'yes' to question 16.

How did the experience of the visit add value to your understanding of visual design and visual exhibitions?

Answered: 22 Skipped: 23

Q18 Do you have other comments to make? 